This is the peer reviewed version of the following article: [Gómez Tello, A. "Which commercial partners are important for the most recently admitted EU countries?" in Economics of Transition (2015), Vol. 23 (1), pp.247-292], which has been published in final form at [http://dx.doi.org/10.1111/ecot.12059]. This article may be used for non-commercial purposes in accordance with Wiley Terms and Conditions for Self-Archiving

\title{
Which commercial partners are important for the most recently admitted EU countries?
}

\author{
Alicia Gómez Tello* \\ Universitat Autònoma de Barcelona
}

January 2015

\begin{abstract}
This paper describes the degree of trade integration inside the European Union (EU) after the fifth enlargement in 2004. To achieve this goal, we build a database of information on trade flows between the new EU countries (EU10) and 180 commercial partners in six different sectors from 1999 to 2011. Using the standard gravity model and estimating a difference-in-differences specification, we analyze how joining the EU affected the intensity and direction of the EU10's trade flows. Our results show that though trade exchanges between the EU10 and EU15 intensified after 2004, the impact of integration was much more significant to the EU10 group.
\end{abstract}

Keywords: European Union, Eastern enlargement, gravity model, trade flow direction.

JEL classification: C13, F14, F15.

\footnotetext{
*I am particularly grateful to R. Nicolini for her continuous encourage, support, and advice and to Florian Mayneris for his helpful discussions. I thank two anonymous referees and the editor for very helpful comments and suggestions. I also want to thank F. Brunet Cid, P.-Ph. Combes, S. Esteve Pérez, S. Gil Pareja, M. Lafourcade, C. López Mayán, T. Mayer, the participants of the Applied Lunch Seminar at the UAB (Barcelona, 2011), the International Workshop on Recent Issues in European Economic Integration and EU Enlargement (Brussels, 2011), the VIII Jornadas sobre Integración Económica (Valencia, 2011), the Doctoral Day (Barcelona, 2012), the XXXVII SAEe (Vigo, 2012), the seminar in the Department of Economics at the University of Liège (Liège, 2013), the IRES internal seminar in international economics (Louvain-la-Neuve, 2013) and the XXVIII Jornadas de Economía Industrial (Segovia, 2013) for their helpful comments. Finally, I acknowledge the Catalonian government project 2014-SGR-327. All remaining errors are my own responsibility. Corresponding to the author: Department of Applied Economics, Universitat Autònoma de Barcelona, Edificio B - Campus de la UAB, 08193 Bellaterra, Barcelona, Spain. Email: alicia.gomez@uab.cat.
} 


\section{Introduction}

The European Union (EU) has experienced one of the most complete integration processes in the world since its creation in 1957. After its fourth enlargement in 1995, the EU was comprised of fifteen countries (EU15). The fifth enlargement in 2004 added ten new member countries (henceforth the EU10). ${ }^{1}$ In principle, trade liberalization is expected to reinforce the intensity of trade flows among EU members. In this context, we aim to investigate the evolution of trade integration among EU members since the fifth enlargement in 2004, namely, between the new and old member countries.

Strong former ties between the EU10 and communist countries made the Eastern enlargement one of the most challenging from an economic viewpoint. A few EU10 members (Estonia, Latvia, and Lithuania) were part of the Union of Soviet Socialist Republics (USSR), and others (Bulgaria, the former Czechoslovakia, Hungary, Poland, and Romania), with the USSR, founded the Council for Mutual Economic Assistance (CMEA or COMECON) in 1949. As a result, these countries shared a remarkable interdependence until 1991, when the USSR collapsed. Nevertheless, during the 1990s, the EU10 and some post-Soviet states continued their strong commercial relationships (Bussière et al., 2008). In this respect, we also investigate how the fifth EU enlargement affected the nature of trade flows between the EU10 and countries of the former Soviet Union (henceforth the FSU).

The instrument selected to develop the empirical analysis is the gravity model. This model has been successful in explaining the intensity and direction of trade flows between countries (Feenstra, 2004; Baier and Bergstrand, 2007; Combes et al., 2008). To perform our empirical exercise, we construct a panel of data at reporter-partner-sector level from 1999 to 2011 using three data sources. The 180 potential EU10 commercial partners are divided into four groups: EU15, EU10, FSU, and the rest of the world (ROW), which is used as the reference. From the standard gravity model, we include a select group of dummy variables (DVs) that capture the variation of the intensity of trade flows between the EU10 and the four commercial partners groups over time. These DVs were designed based on the difference-in-differences (DID) strategy, which is usually used to evaluate the causal effect of implementing a specific program or policy in a target group, the EU10 in this case.

We investigate how the fifth EU enlargement favored a true trade integration between the EU10 and EU15 and how it affected commercial relations between the EU10 and countries of

\footnotetext{
${ }^{1}$ EU10: Cyprus, the Czech Republic, Estonia, Hungary, Latvia, Lithuania, Malta, Poland, Slovakia, and Slovenia.
} 
the FSU. To achieve our objective, we examine variations in the intensity and direction of the EU10's export and import flows. The advantages of referring to both exports and imports are related to the possibility of detecting the factors that could explain the change in the nature of the EU10's trade flows. While the determinants of export flows are associated with the degree of competition among the local producers, the determinants of import flows rely more on the preferences and demand of the destination countries.

Two different (but complementary) estimation exercises are proposed to analyze the potential effects of the EU10's trade flows over time. These exercises differ in how the temporal dimension is managed. In the first exercise, we distinguish two periods: one prior to 2004 (that is, from 1999 to 2003) and one 2004 and later (that is, from 2004 to 2011). The goal is to identify, for each commercial partner group, whether or not the variation of intensity of the EU10's trade flows between the two periods was relatively higher than, equal to, or lower than those for the other groups. We then propose a complementary exercise to check whether or not the results are sensitive to the time period used as the reference. The second exercise analyzes the trend of the intensity of the EU10's trade flows with each commercial partner group during the period 1999-2011, using 1999 as the reference year. This technique emphasizes the specific moment when the fifth EU enlargement affected the intensity of the EU10's trade flows.

We find some remarkable results. We discover that the EU10's export flows to the EU15 and EU10 increased more than to the ROW after 2004, while the exports were redirected from the FSU to the ROW during the years prior to the fifth enlargement. At the sectoral level, we find an interesting heterogeneity in the behavior of the EU10's export flows to the EU15. After 2004, the EU10's export flows to the EU15 increased more than to the ROW in some sectors (chemicals, food and beverages, and manufactured goods classified by material) but less in others (machinery and vehicles, other manufactured articles, and raw materials and energy). This may have been the result partly because of competitiveness issues. That is, in some sectors the EU10 products were not sufficiently competitive for the EU15 markets, and markets outside the EU15 had to be sought. Among imports, we find trade redirection from the ROW to the EU15, EU10, and FSU after 2004. Interestingly, the impact was higher among the EU10; their import flows from the EU10 were greater than from the other groups in nearly all sectors. This result could be explained by a strong bias in the demands of EU10 consumers toward EU10 products.

Finally, we implement two extensions to prove the robustness of the main results. In the former extension, we deal with the missing values problem. Instead of excluding missing values 
from the sample, they are replaced by zeroes (see, for instance, Gleditsch, 2002). Then, an alternative method, the fixed-effects (FE) Poisson maximum-likelihood (ML) estimator, is implemented in order to handle with a sample where the dependent variable has a large proportion of zero values. The latter extension is associated with the strong relationship between trade flows and foreign direct investment (FDI) discussed in the economic literature (Markusen, 2002 is the main reference). We determine whether, after controlling for bilateral FDI, the coefficients of interest change their magnitude and statistical significance. Both extensions confirm that our results are robust.

This paper is organized as follows. Section 2 is a review of the relevant literature. Section 3 is an overview of the international relationships between the EU and other countries, especially those of the FSU. Section 4 focuses on the empirical strategy and at description of the data while Section 5 presents and discusses the results obtained from the two estimation exercises. Section 6 presents the two extensions, proving the robustness of the main results. Finally, Section 7 concludes and addresses policy recommendations.

\section{Literature review}

The Eastern enlargement was not an unpredictable event; since the beginning of the 1990s, some Central and Eastern European countries (CEECs) ${ }^{2}$ expressed interest in joining the EU. For this reason, a relevant part of the literature discusses the degree of trade integration among Western and Eastern Europe during the 1990s. Many studies confirm that there was an important trade integration process among these European areas during the 1990s (Gros and Steinherr, 1995; Brenton and Gros, 1997; Abraham and Konings, 1999; Fontagné et al., 1999; Bussière et al., 2008). Others argue, however, that this integration was far from complete (Faucompret et al. 1999; Paas, 2003).

In particular, Gros and Steinherr (1995) explain that during the 1980s, the trade activity of Central and Eastern Europe (CEE) occurred mostly within the COMECON bloc and that trade among socialist economies accounted for approximately 60 to 70 percent of all CEE trade. From 1989 to 1992, however, CEE trade was redirected toward developed countries, which by 1992 accounted for two thirds of all CEE trade. Brenton and Gros (1997) study the transition processes of the CEECs and post-Soviet states after the dissolution of the USSR by analyzing trade in the intra-Organization for Economic Co-operation and Development (OECD). They

\footnotetext{
${ }^{2}$ Bulgaria, the former Czechoslovakia, Estonia, Hungary, Latvia, Lithuania, Poland, Romania, and Slovenia.
} 
conclude that, in terms of geographical composition, the trade of some CEECs (the Czech Republic, Hungary, and Poland) was indistinguishable from a few EU15 members (Austria and Spain). They thus confirm that in some CEECs there was trade reorientation from the former COMECON partners toward the Western countries, particularly the ones belonging to the EU. Bussière et al. (2008) show that Russia and Ukraine remained important trading partners for CEECs at the end of the 1990s. Conversely, Faucompret et al. (1999) consider that the trade reorientation during the 1990s was incomplete because the EU followed overly restrictive measures for goods imported from non-EU countries. In fact, the EU shifted from being a net importer to a net exporter between 1990 and 1996, meaning that the intensity of the EU's export flows to the CEECs experienced a sharp increase.

Similarly, other studies focus on the effects of European trade agreements on the intensity and direction of trade flows among European countries. Herderschee and Qiao (2007) confirm that the Europe Agreements (EAs) contributed significantly to bilateral trade flows between the EU and some CEECs. Some years later, Egger and Larch (2011) confirm that the EAs fostered trade between the EU and CEECs and reduced trade flows between CEECs and other commercial partners, namely the post-Soviet states and former Yugoslavia. They also find negative intra-group effects; that is, the intensity of trade flows within the EU and within the CEECs decreased.

Despite the abundance of studies on the effects of the trade liberalization process during the 1990s, those that focus on the potential effects on the intensity and direction of the EU10's trade flows after 2004 are limited (Hornok, 2010 and Antimiani and Costantini, 2013 are two of them). In light of the previous discussion, the main contribution of this paper is to provide empirical evidence of the potential effects of the fifth EU enlargement on the EU10's trade flows.

From a technical perspective, this article acknowledges the gravity framework. In the standard gravity model (Tinbergen, 1962), bilateral trade flows are positively correlated with the size of each partner and negatively affected by trade cost. The size of the countries is often measured by the gross domestic product (GDP), while trade cost is measured by the distance between countries. This model has been characterized by the quality of its empirical results. It has been used to estimate the impact of common borders (McCallum, 1995; Nitsch, 2000; Chen, 2004), preferential trading blocs (Carrère, 2004; Baier and Bergstrand, 2007), and currency union (Rose and van Wincoop, 2001; Glick and Rose, 2002), among other things, on the intensity and direction of trade flows. Over time, theoretical underpinnings have been developed to overcome the most important weakness in the gravity model: the absence of any theoretical 
foundation. One of the most complete frameworks providing a theoretical rationale for the gravity model was proposed by Anderson and van Wincoop (2003). Their model predicts that trade flows between two regions depend not only on the trade costs between these two regions but also on the trade costs between these two regions and the ROW, which became known as the multilateral resistance term. They also prove that the standard gravity model, which considers only bilateral trade costs, produces biased results and therefore yields misleading interpretations.

Implementing a gravity framework to study the dynamics resulting from preferential trade agreements (PTAs) is not new. Some studies (for example, Frankel, 1997, chapter 5) introduce two DVs to the standard model equation to capture information about both trade creation and trade diversion. Soloaga and Winters (2001), Carrère (2004), and Westerlund and Wilhelmsson (2011) introduce a third DV to account for the diversion of exports. Unlike these studies, our sample does not allow us to identify the effects of trade creation or trade diversion because our reporter countries are limited to those belonging to the EU10. ${ }^{3}$ Taking into account this limitation, we devise an econometric strategy that exploits the existence of several EU10's commercial partner groups (EU15, EU10, FSU, and ROW) and, at temporal dimension, recognizes the date of their acceptance into the EU (2004). Then, implementing a technique of policy evaluation, the DID strategy, we are able to identify if, after inclusion, they experienced an important variation in the intensity and direction of trade flows.

On the technical side, economists have attempted to improve the specifications of the empirical gravity model to fit theoretical advances. According to Baltagi (2008), the characteristics of the panel econometric framework reduce the probability of obtaining biased results. The first gravitational studies using longitudinal data appeared in the 1990s. Mátyás (1997), for example, estimates the volume of exports in eleven countries of the Asia-Pacific Economic Cooperation (APEC) from 1982 to 1994. He selects two models, one that does not account for fixed effects and one that includes exporter, importer, and year fixed effects. The proposed exercise allows us to detect important differences in the magnitude of the estimated coefficients of the explanatory variables (GDP, population, foreign currency reserves, and real exchange rates) in the two models. Some years later, Egger and Pfaffermayr (2003) exploits Mátyás' data and gravity equation to prove that the correct specification of the gravity model should also include bilateral interaction effects, or exporter-importer fixed effects. Though this type of fixed effects does not allow users to evaluate time-invariant variables such as distance, border, and language, it does capture all unobservable heterogeneity. Baltagi et al. (2003) also include country-time

\footnotetext{
${ }^{3}$ To correctly interpret Vinarian trade creation and trade diversion, we needed a sample with countries belonging to some PTA and, for a control, countries not belonging to any trading bloc.
} 
DVs to control for trends specific to each country. Baldwin and Taglioni (2006) discuss that both the country-pair and the time-country DVs can eliminate what they call 'gold medal' bias (the omitted variable bias or the multilateral resistance term). Nevertheless, they also remark that the inclusion of all these fixed effects generate many DVs and, consequently, an important loss in degrees of freedom. In this study, we introduce different types of fixed effects in our econometric specification. The sectoral dimension of the database (ten sections of the Standard International Trade Classification (SITC)) will be relevant in describing and interpreting parts of our results.

Finally, another important concern in the empirical trade literature is the presence of zero values, which occur frequently when considering bilateral trade flows in a sample with a large number of countries. Santos Silva and Tenreyro (2006) demonstrate that the standard loglinearized gravity equation estimated by ordinary least squares (OLS) produces biased results because of the heteroskedasticity problem and truncation of the data (the log-linearization model drops the zero values). They propose a Poisson pseudo-ML estimation technique to solve both issues. Similarly, Westerlund and Wilhelmsson (2011) show that the standard gravity model estimated by OLS produces biased and inefficient results in the presence of heteroskedasticity and zero trade flow values. They propose a FE Poisson ML estimator using a panel of countries to analyze the effects of the adhesion of Austria, Finland, and Sweden to the EU in 1995 via the intensity of import flows. In light of these results, we perform a robustness exercise, adhering to these methods, to control for the truncation problem in our database.

\section{International context: An overview}

In this section, we provide a synthetic overview of the historical background in Europe, starting with the dissolution of the USSR (1991) and ending in the early 2000s. We first discuss relations between the EU and some CEECs and then describe relations between the EU and countries of the FSU, especially the Russian Federation, the leading member of the USSR.

The CEECs were accustomed to having strong political and economic ties with the USSR. In 1949 the USSR, Bulgaria, Czechoslovakia, Hungary, Poland, and Romania founded the COMECON, with the primary goal of establishing strong economic relationships between socialist countries. Among the EU10, only the Baltic countries (Estonia, Latvia, and Lithuania) were part of the USSR, and they became independent states in 1991. Ten countries in the CEECs applied for EU membership in the early 1990s. As a step toward complete integration, the 
EU decided to sign Europe Agreements (EAs) with them to progressively establish bilateral free trade for manufactured products and ultimately remove all trade barriers between the EU and these CEECs by the end of the 1990s. ${ }^{4}$ In addition, the EAs also aimed to shift national economies from planned to market economies. Nevertheless, according to Baldwin and Wyplosz (2012), these free trade agreements were incomplete because the EU maintained tariffs and trade restrictions on some industrial products. ${ }^{5}$ Importantly, in June 1993, the European Council advanced the integration process by deciding that countries signing the EAs could become official members once they fulfilled the Copenhagen criteria. In May 2004, the fifth EU enlargement occurred and ten new countries received membership.

Since the end of the 1990s, the EU concluded similar partnership and cooperation agreements (PCAs) with Russia and nine Newly Independent States. ${ }^{6}$ These agreements aimed to promote trade and investment among both EU and FSU countries. ${ }^{7}$ At the St. Petersburg Summit in May 2003, the EU and Russia agreed to reinforce their cooperation by gradually creating four common spaces in the framework of the PCA: a common economic space; a common space of freedom, security, and justice; a space of cooperation for external security; and a space of research, education, and cultural exchange. Furthermore, the EU was a strong supporter of Russia joining the World Trade Organization (WTO) from the beginning of the process until its accession in 2012 .

Despite past ties among CEECs and Russia, some controversial situations occurred during the 2000s. Russia imposed a ban on Polish meat imports from 2005 to 2007 because of allegations that Poland exported low-quality, unsanitary meat products. As a consequence, Poland blocked a proposed bilateral treaty between the EU and Russia at the Samara Summit in May 2007. The Baltic countries also reacted against these talks: Estonia complained of Russian cyber attacks upon its government, news media, and banking websites; Lithuania faced a Russian oil blockage; and Latvia opposed Russia's Baltic pipeline plan on environmental grounds (Rettman, 2007).

\footnotetext{
${ }^{4}$ The EU signed EAs in 1991 (Poland and Hungary), 1993 (Bulgaria, the Czech Republic, Romania, and Slovakia), 1995 (Estonia, Latvia, and Lithuania), and 1996 (Slovenia). The agreements came into force approximately two or three years afterward (EC, 2001).

${ }^{5}$ A group of 'sensitive' products (textiles, coal and steel products, and agricultural products) continued to receive strong protection.

${ }^{6}$ The Republic of Armenia, the Republic of Azerbaijan, Georgia, the Republic of Kazakhstan, the Kyrgyz Republic, the Republic of Moldova, Ukraine, the Republic of Uzbekistan, and Tajikistan.

${ }^{7}$ Source: http://europa.eu/legislation_summaries/external_relations/index_en.htm.
} 


\section{Empirical strategy}

In this section we present the empirical strategy implemented to assess the potential effects of the fifth EU enlargement on the EU10's trade flows. We present the empirical strategy in three parts. First, we briefly explain the application of the standard gravity model in international trade. Second, we describe the data and discuss empirical evidence of the evolution of the intensity of the EU10's trade flows with respect to the four commercial partner groups. Finally, we present the econometric specification that will be the reference in developing the two different (but complementary) estimation exercises.

\subsection{The gravity model}

We choose to develop our empirical analysis based on the gravity model because of the results obtained in the empirical literature, in which this model turns out to be successful in describing the intensity and direction of trade flows between countries (Feenstra, 2004; Baier and Bergstrand, 2007; Combes et al., 2008). In the standard gravity model, bilateral trade flows are positively correlated with the size of each partner (usually measured by GDP) and negatively affected by trade cost (usually measured by the distance between partners and other factors that create trade resistance). Denoting the GDP of country $i$ as $G D P_{i}$, the GDP of country $j$ as $G D P_{j}$, the trade flow from country $i$ to country $j$ as $T_{i j}$, and the distance separating them as $d_{i s t} t_{i j}$, the standard gravity model can be written as follows:

$$
T_{i j}=A \frac{G D P_{i}^{\beta_{1}} \times G D P_{j}^{\beta_{2}}}{d i s t_{i j}^{\beta_{3}}},
$$

where $A$ is a constant and $\beta_{1}, \beta_{2}$, and $\beta_{3}$ are unknown parameters. Equation (1) is usually log-linearized and estimated by OLS:

$$
\ln T_{i j}=\ln A+\beta_{1} \ln G D P_{i}+\beta_{2} \ln G D P_{j}-\beta_{3} \ln d i s t_{i j}+u_{i j} .
$$

From this standard gravity model, we introduce a select group of DVs to capture the intensity and direction of the EU10's trade flows after 2004. Our objective is twofold. First, we aim to determine whether or not there was a trade redirection from the ROW in favor of the EU15, EU10, and FSU. Second, we aim to establish whether or not this trade redirection was more important in one group versus the others. 


\subsection{Data}

To implement our empirical strategy we use trade flow data (exports and imports) between the EU10 countries and 180 countries (25 EU countries and 155 non-EU countries) ${ }^{8}$ during the period 1999-2011. For each country-pair entry we distinguish between the reporter and the partner. The reporter is one of the ten countries composing the EU10 (reporting the total value of exports and imports), and the partner is any of the 180 potential commercial partners.

The database has been built using three sources of data. Information on trade flows is extracted from Eurostat's database EU trade since 1988 by SITC. ${ }^{9}$ The SITC divides exports and imports into ten broad sections, numbered 0 through 9 . Following the sectoral classification implemented in Eurostat (2012), the sections are aggregated into six groups: chemicals, food and beverages $(\mathrm{F} \& \mathrm{~B})$, machinery and vehicles, manufactured goods classified by materials, other manufactured articles, and raw materials and energy. ${ }^{10}$ Nominal GDP data are taken from the World Economic Outlook database published by the International Monetary Fund (IMF). ${ }^{11}$ To analyze trade data and GDP in the same nominal currency (current euro), we use the bilateral exchange rate (EUR/USD) reported by Eurostat. ${ }^{12}$ Finally, geographical variables for the gravity model (distance and the dummy variable indicating contiguity) are extracted from the CEPII database's GeoDist (Mayer and Zignago, 2011). Using this information, we construct a panel of data at the reporter-partner-sector level for the period 1999-2011. ${ }^{13}$ The panel structure of the database allows us to better control for heterogeneity because the trade flow intensity between any given two countries in any specific economic activity could be followed through time. The full sample includes 139,620 potential observations. After dropping missing values as in Harris et al., the sample is reduced to 87,125 entries in the case of the exports and 79,848 entries in the case of the imports. ${ }^{14}$

Some empirical evidence of the evolution of the intensity of the EU10's trade flows is presented in Figure 1 (exports in left panels and imports in right panels). Panel 1a is a plot of the

\footnotetext{
${ }^{8}$ The list of countries appears in Appendix A (Tables A.1 and A.2).

${ }^{9}$ This database distinguishes between zeroes and missing values. When a country-pair trade flow is equal to zero, this means 'less than half the final digit shown and greater than real zero;' that is, higher than 0 and less than 0.5 euros. But when a value is missing, this means that the information is unavailable. The database is available at epp.eurostat.ec.europa.eu/portal/page/portal/international_trade/data/database.

${ }^{10}$ Aggregation is as follows: SITC sections 0 and 1 comprise $\mathrm{F} \& \mathrm{~B}, 2$ and 3 comprise raw materials and energy, 5 comprises chemicals, 6 comprises manufactured goods classified by materials, 7 comprises machinery and vehicles, and 8 comprises other manufactured articles.

${ }^{11}$ Available at http://www.imf.org/external/ns/cs.aspx?id=28.

${ }^{12}$ Available at epp.eurostat.ec.europa.eu/portal/page/portal/exchange_rates/data/database.

${ }^{13}$ This period was selected for two reasons. First, Eurostat provides information about the EU10's trade flows only since 1999. Second, the EU10 countries went through a transition process during the 1990s. Our objective is to study the impact of becoming a member of the EU rather than the transition process.

${ }^{14}$ Missing values indicate that data are unavailable for either trade flows or GDP.
} 
EU10's export flows (in billions of euros) for the period 1999-2011. During the entire period, exports to the EU15 were higher than to other groups. The scale of the y-axis does not allow proper appreciation of the trends in exports to the FSU and ROW. Panel 1b presents a correction for this scale effect, normalizing all values so that the exports from the EU10 to any group is equal to 100 in 1999. With this correction, we can see that since the fifth EU enlargement in 2004, export growth rates considerably diverged among the groups. Exports to the EU15 grew at the slowest rate. This could be explained by the EAs signed between the EU15 and some CEECs during the 1990s, which might have anticipated the trade effect of the Eastern enlargement a few years before the official entry. This could also be because the initial level of the EU10's export flows to the EU15 was higher than to the other destinations, influencing export growth rates throughout the period. Panel $1 \mathrm{~b}$ is replicated by sector (see Appendix A, Figure A.1). Exports to the FSU experienced the highest growth rate in three sectors (chemicals, machinery and vehicles, and manufactured goods classified by materials). The EU10's greatest export growth rate in the F\&B sector was to the EU (EU15 and EU10). Exports to the ROW experienced the highest growth rate in the raw materials and energy sector. ${ }^{15}$

We use the same exercise on the import data. Panel 1c is a plot of the EU10's import flows (in billions of euros) for the period 1999-2011. Imports from the EU15 were higher than from other groups. To avoid the scale effect, the data were normalized in the same way as the export data, and are presented in Panel 1d. Import growth rates varied among commercial partner groups at the beginning of the period and intensified after 2004. The intensity of the EU10's import flows from the EU10 experienced the highest growth rate. This result, generalized for all sectors, was specially notable in machinery and vehicles and the other manufactured articles sectors (see Appendix A, Figure A.2).

\footnotetext{
${ }^{15}$ According to the official web page of the EU (http://europa.eu/index en.htm), Poland is rich in natural mineral resources such as iron, zinc, copper, and rock salt, while Hungary is endowed with other natural resources (for example, bauxite, coal, and natural gas).
} 

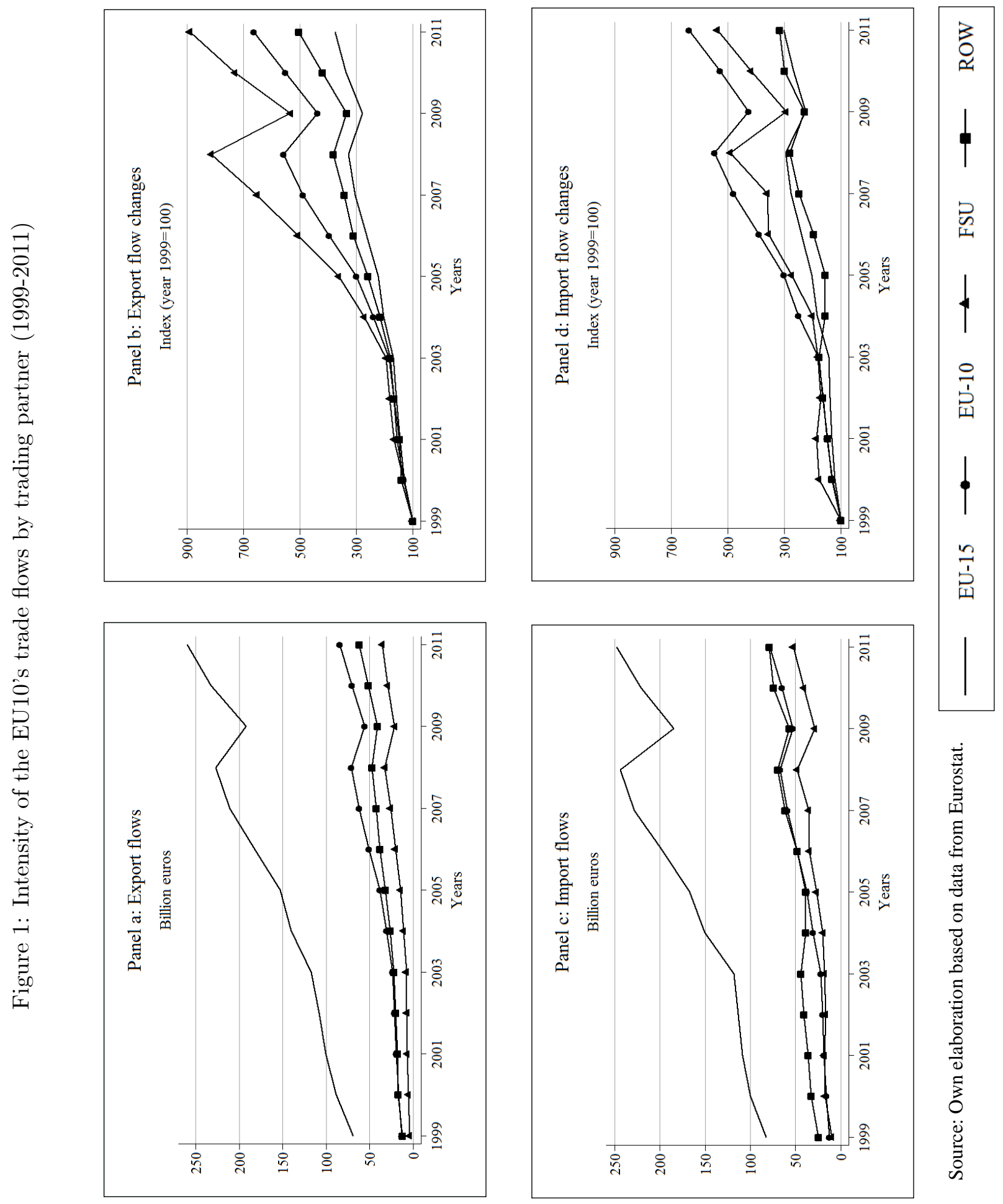


\subsection{Econometric specification}

In this subsection we describe in detail the two estimation strategies implemented to study the potential effects of the fifth EU enlargement on the intensity and direction of the EU10's trade flows. The standard gravity model (Equation 2) is augmented by including a set of fixed effects:

$$
\begin{aligned}
\ln T_{i j s t}= & \beta_{0}+\beta_{1} \ln G D P_{i t}+\beta_{2} \ln G D P_{j t}+\beta_{3} \ln d i s t_{i j}+\beta_{4} \text { border }_{i j}+ \\
& +\alpha_{i}+\eta_{j}+\delta_{s}+\theta_{t}+\varepsilon_{i j s t} \\
& \quad i=1, \ldots, 10, j=1, \ldots 180(i \neq j), s=1, \ldots, 6, t=1999, \ldots 2011,
\end{aligned}
$$

where $i$ is the reporter country, $j$ is the partner country, $s$ is the sector, and $t$ is the year. The dependent variable $\left(\ln T_{i j s t}\right)$ is the logarithm of the annual exports $\left(X_{i j s t}\right)$ or imports $\left(M_{i j s t}\right)$ in sector $s$ and year $t$ (in current euro). ${ }^{16}$ This dependent variable is expected to be affected by a constant $\left(\beta_{0}\right),{ }^{17}$ the logarithm of the reporter's GDP in year $t\left(\ln G D P_{i t}\right)$, the logarithm of the partner's GDP in year $t\left(\ln G D P_{j t}\right)$, the logarithm of the distance between the reporter and the partner $\left(\ln d i s t_{i j}\right)$, a dummy variable that indicates if the reporter and partner share a common border $\left(\right.$ border $\left._{i j}\right)$, and the error term $\left(\varepsilon_{i j s t}\right)$. These explanatory variables are part of the standard gravity model and control for the countries' sizes and for the trade costs between any two commercial partners. The signs of the coefficients $\beta_{1}, \beta_{2}$, and $\beta_{4}$ are expected to be positive, indicating that the intensity of trade flows between two commercial partners increases with the size of their economies as well as their cultural links (measured by the border dummy variable), while $\beta_{3}$ is expected to be negative, indicating that the intensity of trade flows between two commercial partners decreases with their geographical distance. Moreover, in this econometric specification, we control for unobserved individual characteristics, namely fixed effects of the reporter $\left(\alpha_{i}\right)$, partner $\left(\eta_{j}\right)$, sector $\left(\delta_{t}\right)$, and time $\left(\theta_{t}\right){ }^{18}$ We refer to Equation (3) as the baseline specification for our two econometric exercises. ${ }^{19}$

\footnotetext{
${ }^{16}$ The sample has a potential of 139,620 observations (that is, $10 \cdot 179 \cdot 13 \cdot 6=139,620$ ). Concerning the trade flow data, there are a lot of missing values (37 percent in the case of exports and 43 percent in the case of imports), but the number of zeroes is small (233 in the case of exports and 456 in the case of imports). In Sections 4 and 5 we address the zero values problem by adding one unit to the trade flow data before taking logarithms (Chen, 2004), while missing values are excluded from the sample (Harris et al., 2012). We need to take care of the potential bias that the exclusion of missing values might have on estimations (Gleditsch, 2002).

${ }^{17}$ For the sake of simplicity $\ln A$ in Equation (2) has been replaced by $\beta_{0}$.

${ }^{18}$ In this study, time fixed effects control for economic events that affect all countries and sectors, such as a financial crisis.

${ }^{19}$ We then introduce several fixed effects according to the dimension of the panel to properly control for the heterogeneity problem.
} 
With the objective of determining the impact of the fifth EU enlargement on the intensity and direction of the EU10's trade flows, we introduce in the baseline specification (3) a select group of DVs based on the DID strategy. This strategy is typically used to measure the causal effect of implementing a specific program or policy in a target group. In our case, the fifth EU enlargement represented a larger single market, completing a set of twenty-five countries that exchange goods and services without tariffs or quantitative controls. Our target group is those countries comprising the EU10, and we are interested in measuring the effectiveness of the EU enlargement for this specific group. One canonical feature of the DID strategy is the choice of a temporal break, usually related to the time the policy is implemented. We thus define two complementary exercises. In the former, the temporal break corresponds to the year of the fifth EU enlargement (2004), and on the latter we do not make such a choice.

Our first empirical exercise proposes a pure DID strategy with the objective of determining whether or not the new EU member (the EU10) experienced a change in intensity of their trade flows after becoming part of the existing single market. After defining our temporal periods and four partner groups we created several DVs: af04 equals one when the year is 2004 or later; eu15 equals one when the partner belongs to the EU15; eu10 equals one when the partner belongs to the EU10; and $f s u$ equals one when the partner belongs to the FSU. We interact the temporal DV with the three partner DVs to generate commercial partner DVs after 2004, namely, eu15 $5_{a f 04}, e u 10_{a f 04}$, and $f s u_{a f 04} \cdot{ }^{20}$ These DVs are added to the baseline specification (3) to get the following expression:

$$
\begin{aligned}
\ln T_{i j s t}= & \beta_{0}+\beta_{1} \ln G D P_{i t}+\beta_{2} \ln G D P_{j t}+\beta_{3} \ln \text { dist }_{i j}+\beta_{4} \text { border }_{i j}+ \\
& +\gamma_{\text {eu } 15}^{a f 04} \text { eu } 15_{a f 04}+\gamma_{\text {eu } 10}^{a f 04} e u 10_{a f 04}+\gamma_{f s u}^{a f 04} f s u_{a f 04}+ \\
& +\gamma_{\text {eu } 15} \text { eu } 15+\gamma_{\text {eu } 10} \text { eu } 10+\gamma_{f s u} f s u+a f 04+\alpha_{i}+\eta_{j}+\delta_{s}+\theta_{t}+\varepsilon_{i j s t} \\
& i=1, \ldots, 10, j=1, \ldots 180(i \neq j), s=1, \ldots, 6, t=1999, \ldots 2011 .
\end{aligned}
$$

The countries belonging to the ROW and the period 1999-2003 are the references (or control groups) used to interpret the econometric results. Therefore, the coefficient $\gamma_{g}^{a f 04}(g=e u 15$, eu10, or fsu) in Equation (4) can be expressed as follows:

\footnotetext{
${ }^{20}$ For instance, the DV eu15af04 equals one when the partner belongs to the EU15 and the year is 2004 or later.
} 


$$
\gamma_{g}^{a f 04}=\left(\bar{T}_{g, a f 04}-\bar{T}_{g, b e f 04}\right)-\left(\bar{T}_{\text {row }, a f 04}-\bar{T}_{\text {row }, b e f 04}\right)
$$

where $\bar{T}$ represents the annual average level of trade flows (exports or imports) for the corresponding period (bef04 refers to the period 1999-2003, while af04 refers to the period 20042011). In other words, the coefficient $\gamma_{g}^{a f 04}$ describes the increase in the exports (or imports) between the two defined periods by comparing group $g$ versus the ROW. A positive sign indicates that the intensity of the EU10's export flows (or import flows) increased to (from) group $g$ more than it did to (from) the ROW, which could be interpreted as trade redirection from the ROW to group $g .{ }^{21}$ A priori $\gamma_{e u 15}^{a f 04}$ and $\gamma_{e u 10}^{a f 04}$ are expected to be positive and $\gamma_{f s u}^{a f 04}$ is expected to be negative. In other words, we expect trade redirection from the ROW to the EU countries (EU15 and EU10) because they are part of the same economic community, and we expect no such effect to the FSU.

Because trade flow data is reported annually, 2004 (the year of the fifth EU enlargement) has to be included in either the treatment or control group. In the first exercise, it is included in the treatment group. ${ }^{22}$ To test whether this decision could determine the results, we propose a second exercise where each commercial partner DV (eu15, eu10, and fsu) interacts with the temporal DVs, now defined for each year. Using 1999 as the time reference, we can study the tendency of each group throughout the entire period, year by year. ${ }^{23}$ To do this, we introduce in the baseline specification (3) a new set of DVs, and the equation becomes:

$$
\begin{gathered}
\ln T_{i j s t}=\beta_{0}+\beta_{1} \ln G D P_{i t}+\beta_{2} \ln G D P_{j t}+\sum_{t=2000}^{2011} \gamma_{e u 15}^{t} e u 15^{t}+\sum_{t=2000}^{2011} \gamma_{e u 10}^{t} e u 10^{t}+\sum_{t=2000}^{2011} \gamma_{f s u}^{t} f s u^{t}+\lambda_{i j s}+\theta_{t}+\varepsilon_{i j s t} \\
i=1, \ldots, 10, j=1, \ldots 180(i \neq j), s=1, \ldots, 6, t=1999, \ldots 2011
\end{gathered}
$$

where $e u 15^{t}$, eu10 ${ }^{t}$, and $f s u^{t}$ are the commercial partner DVs in year $t$ and $\lambda_{i j s t}$ is the threedimensioned fixed effects (at the reporter-partner-sector level). ${ }^{24}$

\footnotetext{
${ }^{21}$ It is important to take into account that this coefficient must be interpreted as differences and not as levels. If $\gamma_{g}^{a f 04}>0$, we cannot claim that the level of exports to group $g$ was higher than the level of exports to the ROW, yet we can claim that the increase in export flows to group $g$ was higher than the increase in export flows to the ROW.

${ }^{22}$ Hornok (2010) tackles the mid-year accession problem by considering only the odd years. In this case, the treatment group includes the years 2005 and 2007, and the control group includes the years 1999, 2001, and 2003.

${ }^{23}$ Carrère (2004) and Head et al. (2010) propose a similar exercise to study the effects of regional trade agreements and former colonies, respectively, on the intensity of trade flows along a period of time.

${ }^{24}$ Because we consider reporter-partner-sector fixed effects, we indirectly consider the effect of each commercial

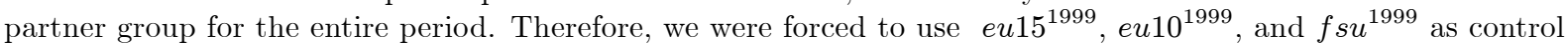
groups.
} 
This technique allows us to compare the changes in the intensity of trade flows between the EU10 and each commercial partner group $g$ against the changes in the intensity of trade flows between the EU10 and the ROW for any period of time. For example, the coefficient of the partner group $g$ multiplied by the year dummy year 03 is equal to:

$$
\gamma_{g}^{2003}=\left(\bar{T}_{g, 2003}-\bar{T}_{g, 1999}\right)-\left(\bar{T}_{\text {row }, 2003}-\bar{T}_{\text {row }, 1999}\right)
$$

where $\bar{T}$ represents the annual average level of trade flows (exports or imports). The coefficient

$\gamma_{g}^{2003}$ describes the change in the intensity of trade flows between 1999 and 2003 between two groups, group $g$ and the ROW. A positive (negative) sign indicates that the trade variation was higher (lower) for group $g$ than for the ROW.

This technique is more flexible than the usual DID strategy in the way it manages the temporal dimension. In addition, it emphasizes the precise moment at which the trade variation took place, using 1999 as the reference. Henceforth, we refer to the first econometric specification as the DID strategy defined by Equation (4), and the second as the trend of the commercial partner groups over time defined by Equation (6).

\section{Results}

To present the results clearly, this section is divided into two parts. The first focuses on the standard DID strategy and the second on the trend analysis. For the first time, we study the effects of the EU accession on both the EU10's export and import flows. Changes in export flows usually rely on competitiveness factors (Antimiani and Costantini, 2013), while changes in import flows are associated with trade creation and trade diversion mechanisms created by the existence of a regional trade agreement (Carrère, 2004). We compute, in each exercise, the effects based on all the sectors jointly and again with each sector individually. The latter exercise allows us to identify the existence of sector-specific effects that could be hidden if the analysis were done only on all sectors jointly.

\subsection{Difference-in-differences strategy}

The objective of this estimation exercise is to assess whether or not there was variation in the intensity of the EU10's trade flows after 2004. To this end, we split the time period into two parts and compare the level of the EU10's trade flows between the two periods for each of the 
four commercial partner groups, as described by Equation (4).

Focusing on export flows and taking all sectors jointly, the results in Table 1 are presented according to the way heterogeneity has been controlled, by including various fixed effects and interactions. In column 1, the estimation is run by OLS and all individual fixed effects are considered (that is, reporter $\left(\alpha_{i}\right)$, partner $\left(\eta_{i}\right)$, sector $\left(\delta_{i}\right)$, and year $\left(\theta_{t}\right)$ ). Column 2 includes the reporter-partner fixed effects $\left(\mu_{i j}\right)$. Because these fixed effects capture all the time invariant characteristics, some variables (ln dist $t_{i j t}$ and border $_{i j t}$ ) are dropped. ${ }^{25}$ Finally, column 3 includes the reporter-partner-sector fixed effects $\left(\lambda_{i j s}\right)$. The model is run using the fixed-effects (FE) or within transformation estimator. In all cases, the standard errors (SEs) are clustered at the reporter-partner level, then some dependence among country-pairs is allowed.

We discuss only the results in column 3 , which is our preferred specification. The coefficients of the GDP were positive and statistically significant. If the exporting country's GDP increased by one percent, the export flows increased by 0.87 percent; if the importing country's GDP increased by one percent, the export flows increased by 0.68 percent. As expected, the coefficients $\widehat{\gamma}_{e u 15}^{a f 04}$ and $\widehat{\gamma}_{e u 15}^{a f 04}$ were positive and statistically significant, meaning that after 2004 the variation of the intensity of the EU10's export flows to the EU15 and EU10 increased more than that to the ROW. Specifically, the EU10's export flows to the EU15 and EU10 increased by 14.85 percent and 23.93 percent, respectively, versus the reference group. ${ }^{26}$ If we compare these two coefficients we cannot reject the null hypothesis that their difference is equal to zero. Therefore, we can conclude that after 2004 there was a trade integration process toward the EU, meaning that the EU10 found EU markets attractive for selling their products. Furthermore, the coefficient $\widehat{\gamma}_{f s u}^{a f 04}$ was not statistically different from zero, meaning that after 2004, the variation of the EU10's export flows to the FSU was not different from that to the ROW.

From an econometric viewpoint two comments must be made. First, the introduction of fixed effects that account for more than one dimension affected the magnitude and significance of the coefficients of interest, namely $\widehat{\gamma}_{e u 15}^{a f 4}, \widehat{\gamma}_{e u 10}^{a f 04}$, and $\widehat{\gamma}_{f s u}^{a f 04}$. The last of these was positive and statistically significant in the first two specifications but not in the last. Second, column 3 reports a constant, but its interpretation is not very intuitive. The within transformation model considers more than 9,000 unobserved individual effects, one for each reporter-partnersector combination (there are 9,369 groups), and an intercept is estimated for each reporter-

\footnotetext{
${ }^{25}$ To run this regression we employed the program reg2hdfe in Stata, implementing the algorithm developed by Guimarães and Portugal (2010). This program allows us to control for high-dimensional fixed effects (in our case reporter-partner) without incurring in storage problems. But it does not report a constant.

${ }^{26}$ For example, $\widehat{\gamma}_{\text {eu15 }}^{a f 04}=0.1385$ indicates that the increase in exports was equal to $[\exp (0.1385)-1] \cdot 100=14.85$ percent (Halvorsen and Palmquist, 1980).
} 
partner-sector combination $\left(\widehat{\lambda}_{i j s}\right)$. The constant reported by the FE model $\left(\widehat{\beta}_{0}\right)$ is the average of them all (Wooldridge, 2006), but also captures the average values of the quantitative regressors $\left(\ln G D P_{i t}\right.$ and $\left.\ln G D P_{j t}\right)$ and the effects of the control groups of the DVs (namely, row, year99, and year04).

Another interesting exercise is to assess whether or not the effects of the fifth EU enlargement on the intensity and direction of the EU10's export flows were homogeneous across all sectors. Table 2 reports the results for the FE model by sector. In the chemicals and F\&B sectors, we see trade redirection from the ROW to the other partner groups. The greatest impact in the $\mathrm{F} \& \mathrm{~B}$ exports was to the EU15. ${ }^{27}$ The machinery and vehicles sector (Machinery) is one of the most heterogeneous sectors in the sense that it is composed of several types of products of different qualities. The estimation referring to this sector emphasizes that after 2004, the EU10 experienced export redirection from the EU15 to the ROW, meaning that the intensity of the EU10's export flows to the ROW increased more than that to the EU15. An explanation could be related to competitiveness: the quality of the products from the EU10 might not fit well with the preferences of the EU15, causing the EU10 to search for new markets. This argument is supported by the evidence discussed in Head and Mayer (2004), where trade is found to be more attractive between countries with similar GDPs because citizens' preferences are more comparable. Exports of manufactured goods classified by material (Manufbymat) were redirected from the ROW to the other groups. Exports of other manufactured articles (Othermanuf) were redirected from the EU15 and FSU to the ROW. The argument put forth for the machinery and vehicle sector holds for this sector as well, which includes goods of high technological worth. ${ }^{28}$ Finally, exports of raw materials and energy (Rawmat) were redirected from the EU15 and FSU to the ROW. This is not surprising because Russia, the largest country of the FSU, is a major exporter of gas, and the EU is a major importer of Russian natural gas (Noël, 2008).

Hence, our results suggest that the effects of the fifth EU enlargement on the EU10's export flows to the EU15 were not homogeneous across all sectors. We find that after 2004, the EU10's export flows to the EU15 increased more than those to the ROW in some sectors (chemicals, $\mathrm{F} \& \mathrm{~B}$, and manufactured goods by material), but increased less in others (machinery and vehicles,

\footnotetext{
${ }^{27}$ The coefficient $\widehat{\gamma}_{e u 15}^{a f 04}$ was statistically different from the other two coefficients $\left(\widehat{\gamma}_{e u 10}^{a f 04}\right.$ and $\left.\widehat{\gamma}_{f s u}^{a f 04}\right)$ at the one percent level. According to the EU official web page (http://europa.eu/index_en.htm), the Czech Republic produces a world-famous beer (namely, Pilsner) and wine. The Hungarian wines (for example, Tokaji) are also known worldwide.

${ }^{28}$ For example, Division 87 of the SITC comprises professional, scientific and controlling instruments and apparatus, n.e.s., while Division 88 comprises photographic apparatus, equipment and supplies and optical goods, n.e.s.; watches and clocks (UN, 2006).
} 
Table 1: EU10's export flows (all sectors)

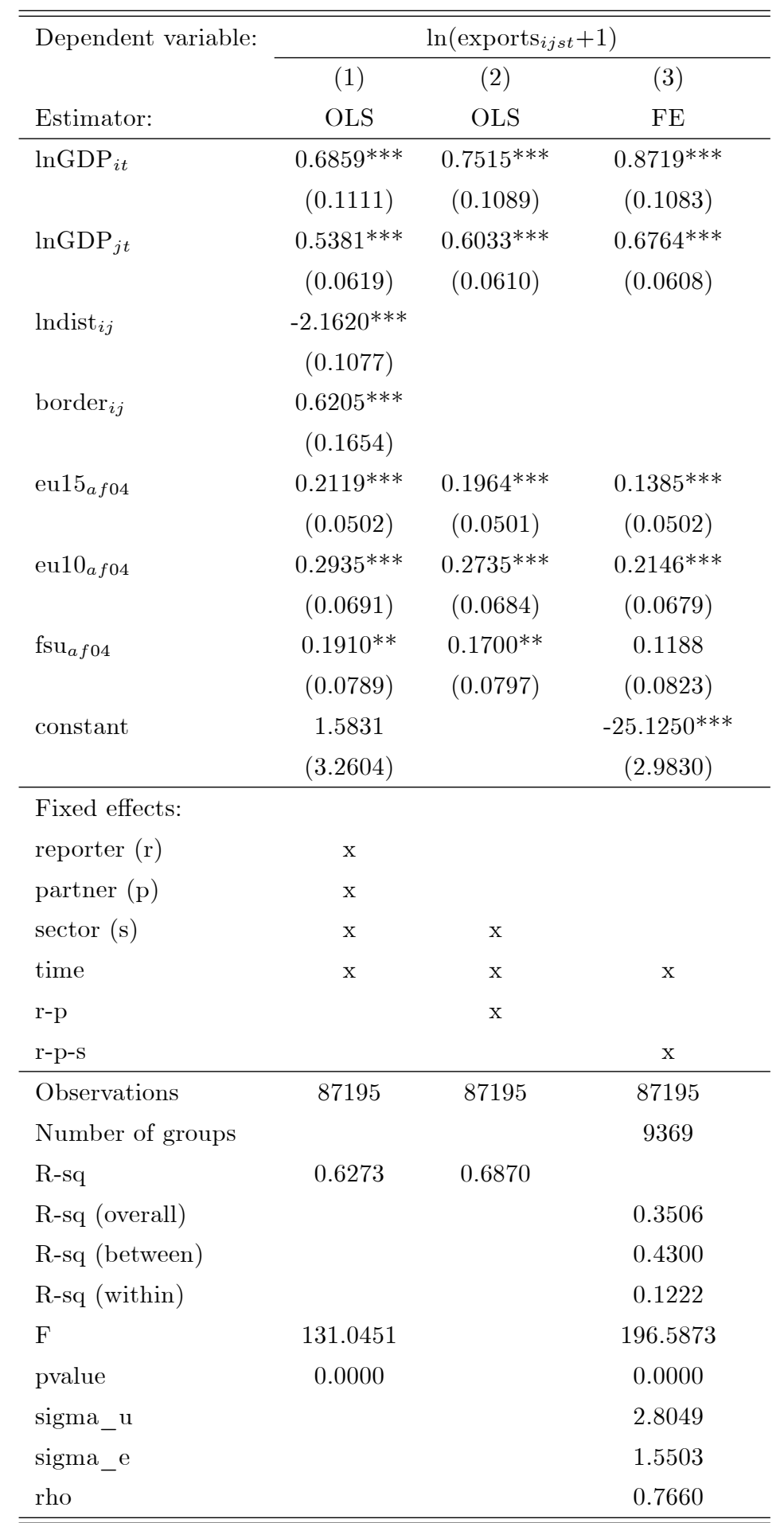

Standard errors clustered by reporter-partner are in parenthesis.

${ }^{*} p<0.10,{ }^{* *} p<0.05,{ }^{* * *} p<0.01$

Specification (1) includes the DVs eu15, eu10, fsu, and af04.

Specifications (2) and (3) include the DV af04. 
Table 2: EU10's export flows (by sector)

\begin{tabular}{|c|c|c|c|c|c|c|}
\hline & \multicolumn{6}{|c|}{ Dependent variable: $\ln \left(\operatorname{exports}_{i j t}+1\right)$ - Estimator: FE } \\
\hline & Chemicals & $F \& B$ & Machinery & Manufbymat & Othermanuf & Rawmat \\
\hline \multirow[t]{2}{*}{$\ln \mathrm{GDP}_{i t}$} & 0.3312 & 0.1487 & $1.9443^{* * *}$ & $0.4903^{* *}$ & $1.2729^{* * *}$ & 0.3354 \\
\hline & $(0.2276)$ & $(0.2635)$ & $(0.1756)$ & $(0.2113)$ & $(0.2169)$ & $(0.2806)$ \\
\hline \multirow{2}{*}{$\operatorname{lnGDP}_{j t}$} & $0.6046^{* * *}$ & $0.2358^{*}$ & $0.8182^{* * *}$ & $0.6956^{* * *}$ & $0.7543^{* * *}$ & $0.9544^{* * *}$ \\
\hline & $(0.1128)$ & $(0.1423)$ & $(0.1043)$ & $(0.1154)$ & $(0.1220)$ & $(0.1453)$ \\
\hline \multirow[t]{2}{*}{ eu15af04 } & $0.5447^{* * *}$ & $1.1560^{* * *}$ & $-0.2480^{* * *}$ & $0.1620^{* *}$ & $-0.3538^{* * *}$ & $-0.4051^{* * *}$ \\
\hline & $(0.1162)$ & $(0.1240)$ & $(0.0795)$ & $(0.0823)$ & $(0.0879)$ & $(0.1232)$ \\
\hline \multirow[t]{2}{*}{ eu10 $0_{a f 04}$} & $0.3214^{*}$ & $0.7485^{* * *}$ & -0.1585 & $0.5386^{* * *}$ & -0.0713 & -0.0387 \\
\hline & $(0.1679)$ & $(0.1532)$ & $(0.1109)$ & $(0.1210)$ & $(0.1125)$ & $(0.1564)$ \\
\hline \multirow[t]{2}{*}{$\mathrm{fsu}_{a f 04}$} & $0.2588^{* *}$ & $0.3999^{* *}$ & 0.2213 & $0.4977^{* * *}$ & $-0.2457^{*}$ & $-0.3849^{* *}$ \\
\hline & $(0.1220)$ & $(0.1576)$ & $(0.1450)$ & $(0.1571)$ & $(0.1451)$ & $(0.1946)$ \\
\hline \multirow[t]{2}{*}{ constant } & $-10.6567^{*}$ & 2.8638 & $-53.4858 * * *$ & $-15.9440^{* * *}$ & $-37.0651^{* * *}$ & $-19.9111^{* * *}$ \\
\hline & $(6.1788)$ & $(7.0843)$ & $(4.9601)$ & $(5.9512)$ & $(5.7887)$ & $(7.3706)$ \\
\hline Observations & 14783 & 12725 & 16624 & 15357 & 16074 & 11632 \\
\hline Number of groups & 1579 & 1502 & 1684 & 1605 & 1639 & 1360 \\
\hline R-sq (overall) & 0.3509 & 0.2373 & 0.4252 & 0.4226 & 0.3662 & 0.2313 \\
\hline R-sq (between) & 0.4264 & 0.3081 & 0.5308 & 0.5324 & 0.4726 & 0.2628 \\
\hline R-sq (within) & 0.1629 & 0.0773 & 0.2336 & 0.0508 & 0.1286 & 0.1726 \\
\hline $\mathrm{F}$ & 64.2422 & 31.4486 & 113.6239 & 25.8378 & 55.2661 & 52.8541 \\
\hline pvalue & 0.0000 & 0.0000 & 0.0000 & 0.0000 & 0.0000 & 0.0000 \\
\hline sigma_u & 2.7705 & 3.0871 & 2.5345 & 2.8864 & 2.6771 & 2.9600 \\
\hline sigma_e & 1.4272 & 1.6625 & 1.4392 & 1.5060 & 1.5697 & 1.6434 \\
\hline rho & 0.7903 & 0.7752 & 0.7562 & 0.7860 & 0.7442 & 0.7644 \\
\hline
\end{tabular}

Standard errors clustered by reporter-partner are in parenthesis.

$* p<0.10, * * p<0.05, * * * x<0.01$

Fixed-effects dimension: reporter-partner $\left(\mu_{i j}\right)$. All regressions include time DVs (af04 and $\left.\theta_{t}\right)$. 
other manufactured articles, and raw materials and energy).

To complete our first estimation exercise, we apply the same empirical analysis to the EU10's imports. First, all sectors are analyzed jointly (Table 3). Again, we focus on the results in the third column, containing the FE model. The coefficients of the GDP were positive and statistically significant. If the importing country's GDP increased by one percent, the import flows increased by 0.62 percent; if the exporting country's GDP increased by one percent, the import flows increased by 0.24 percent. We observe that the increase in the intensities of the EU10's import flows from the EU15, EU10, and FSU were higher than those from the ROW. Nevertheless, the most important change occurred from the EU10 $\left(\widehat{\gamma}_{e u 10}^{a f 04}=1.22\right) .{ }^{29}$ Therefore, trade liberalization had an important impact on internal EU10 trade flows, which could be related to time-variant bias in EU10 consumer preferences; the EU10's buyers might have perceived EU10 products ipso facto to be different from non-EU10 products. Hence, buyers preferred to import commodities from EU10 countries instead of from EU15 countries, which illustrates a group-biased demand effect. ${ }^{30}$ Unlike that seen among exports, the incorporation of fixed effects that captures more than one dimension did not affect the magnitude of the coefficients of interest as much.

To assess whether or not the variation of the intensity of the EU10's import flows was common among all sectors, we propose sectoral analysis (Table 4). It is important to remark that the capacity of prediction of the model for changes in the EU10's import flows (by sector) is more limited than the one for exports. We find that the EU10 increased its import flows more from the FSU than from the ROW in chemicals, F\&B, and other manufactured articles sector, while the EU10 increased its import flows more from the EU15 and EU10 than from the ROW in all sectors. In addition, except for the $\mathrm{F} \& \mathrm{~B}$, the highest variation was within the EU10, meaning that group-biased demand was a generalized effect that extended to almost all sectors.

\footnotetext{
${ }^{29}$ The coefficient $\widehat{\gamma}_{e u 10}^{a f 04}$ was statistically different from the other two coefficients $\left(\widehat{\gamma}_{e u 15}^{a f 04}\right.$ and $\left.\widehat{\gamma}_{f s u}^{a f 04}\right)$ at the one percent level.

${ }^{30}$ Head and Mayer (2000) use the home-biased demand assumption to explain EU market fragmentation in the mid-1980s.
} 
Table 3: EU10's import flows (all sectors)

\begin{tabular}{lccc}
\hline \hline Dependent variable: & \multicolumn{3}{c}{$\ln \left(\right.$ imports $\left._{i j s t}+1\right)$} \\
\cline { 2 - 4 } Estimator: & OLS & OLS & FE \\
\hline $\operatorname{lnGDP}_{i t}$ & $0.3732^{* * *}$ & $0.3870^{* * *}$ & $0.6169^{* * *}$ \\
& $(0.1263)$ & $(0.1255)$ & $(0.1213)$ \\
$\operatorname{lnGDP}_{j t}$ & $0.2260^{* * *}$ & $0.2326^{* * *}$ & $0.2440^{* * *}$ \\
& $(0.0702)$ & $(0.0708)$ & $(0.0681)$ \\
$\operatorname{lndist}_{i j}$ & $-1.9184^{* * *}$ & & \\
& $(0.1040)$ & & \\
border $_{i j}$ & $0.6932^{* * *}$ & & \\
& $(0.1889)$ & & $(0.0491)$ \\
eu15 $_{a f 04}$ & $0.5943^{* * *}$ & $0.6078^{* * *}$ & $0.6963^{* * *}$ \\
& $(0.0480)$ & $(0.0484)$ & $(0.0864)$ \\
eu10 $_{a f 04}$ & $1.0733^{* * *}$ & $1.0998^{* * *}$ & $1.2158^{* * *}$ \\
& $(0.0878)$ & $(0.0884)$ & $(0.0951)$ \\
fsu $_{a f 04}$ & $0.4839^{* * *}$ & $0.4672^{* * *}$ & $0.4509^{* * *}$ \\
& $(0.0986)$ & $(0.1022)$ & $(3.2999)$ \\
constant & $9.7911^{* * *}$ & & $-8.5088^{* *}$ \\
& $(3.5842)$ & & $(3)$ \\
\hline
\end{tabular}

\begin{tabular}{lccc}
\hline $\begin{array}{l}\text { Fixed effects: } \\
\text { reporter (r) }\end{array}$ & $\mathrm{x}$ & & \\
partner (p) & $\mathrm{x}$ & & \\
sector (s) & $\mathrm{x}$ & $\mathrm{x}$ & \\
time & $\mathrm{x}$ & $\mathrm{x}$ & $\mathrm{x}$ \\
r-p & & $\mathrm{x}$ & \\
r-p-s & & & $\mathrm{x}$ \\
\hline Observations & 79848 & 79848 & 79848 \\
Number of groups & & & 9003 \\
R-sq & 0.6715 & 0.7099 & \\
R-sq (overall) & & & 0.2964 \\
R-sq (between) & & & 0.3961 \\
R-sq (within) & & & 0.0355 \\
F & 285.2938 & & 75.6782 \\
pvalue & 0.0000 & & 0.0000 \\
sigma_u & & & 3.9221 \\
sigma_e & & & 1.5972 \\
rho & & & 0.8577 \\
\hline \hline
\end{tabular}

Standard errors clustered by reporter-partner are in parenthesis.

${ }^{*} p<0.10,{ }^{* *} p<0.05,{ }^{* * *} p<0.01$

Specification (1) includes the DVs eu15, eu10, fsu, and af04.

Specifications (2) and (3) include the DV af04. 
Table 4: EU10's import flows (by sector)

\begin{tabular}{|c|c|c|c|c|c|c|}
\hline & \multicolumn{6}{|c|}{ Dependent variable: $\ln \left(\right.$ imports $\left._{i j t}+1\right)$ - Estimator: FE } \\
\hline & Chemicals & $\mathrm{F} \& \mathrm{~B}$ & Machinery & Manufbymat & Othermanuf & Rawmat \\
\hline \multirow[t]{2}{*}{$\ln \mathrm{GDP}_{i t}$} & 0.0660 & 0.1848 & $1.0004^{* * *}$ & $1.1158^{* * *}$ & $0.9785^{* * *}$ & 0.1472 \\
\hline & $(0.2630)$ & $(0.2311)$ & $(0.2407)$ & $(0.2116)$ & $(0.2026)$ & $(0.2695)$ \\
\hline \multirow{2}{*}{$\operatorname{lnGDP}_{j t}$} & -0.0969 & $0.2738^{* *}$ & $0.6156^{* * *}$ & 0.1773 & $0.3341^{* * *}$ & 0.0135 \\
\hline & $(0.1568)$ & $(0.1341)$ & $(0.1330)$ & $(0.1384)$ & $(0.1175)$ & $(0.1518)$ \\
\hline \multirow[t]{2}{*}{ eu15af04 } & $0.3488^{* * *}$ & $1.2846^{* * *}$ & $0.4000^{* * *}$ & $0.4585^{* * *}$ & $0.8014^{* * *}$ & $0.6985^{* * *}$ \\
\hline & $(0.0927)$ & $(0.0903)$ & $(0.0834)$ & $(0.0740)$ & $(0.0692)$ & $(0.1200)$ \\
\hline \multirow[t]{2}{*}{$\mathrm{eu} 10_{a f 04}$} & $1.3801^{* * *}$ & $1.5234^{* * *}$ & $0.9277^{* * *}$ & $1.0230^{* * *}$ & $1.0568^{* * *}$ & $1.2715^{* * *}$ \\
\hline & $(0.1689)$ & $(0.1550)$ & $(0.1433)$ & $(0.1456)$ & $(0.1272)$ & $(0.1771)$ \\
\hline \multirow[t]{2}{*}{$\mathrm{fsu}_{a f 04}$} & $0.7397^{* * *}$ & $0.8309^{* * *}$ & 0.0523 & 0.3515 & $0.7604^{* * *}$ & 0.0038 \\
\hline & $(0.2309)$ & $(0.1905)$ & $(0.2003)$ & $(0.2181)$ & $(0.1909)$ & $(0.2277)$ \\
\hline \multirow[t]{2}{*}{ constant } & $13.1428^{*}$ & 1.5326 & $-26.6676^{* * *}$ & $-18.7123^{* * *}$ & $-19.8917^{* * *}$ & 8.3681 \\
\hline & $(7.3710)$ & $(6.4755)$ & $(6.6953)$ & $(6.0676)$ & $(5.5840)$ & $(7.3220)$ \\
\hline Observations & 10726 & 14081 & 13821 & 13520 & 15444 & 12256 \\
\hline Number of groups & 1294 & 1537 & 1586 & 1522 & 1637 & 1427 \\
\hline R-sq (overall) & 0.0008 & 0.3936 & 0.3896 & 0.0905 & 0.2583 & 0.1112 \\
\hline R-sq (between) & 0.0118 & 0.5209 & 0.4890 & 0.1484 & 0.3630 & 0.1976 \\
\hline R-sq (within) & 0.0696 & 0.0522 & 0.0507 & 0.0314 & 0.0341 & 0.0368 \\
\hline $\mathrm{F}$ & 27.5769 & 30.6800 & 33.2839 & 21.3612 & 23.3854 & 19.4571 \\
\hline pvalue & 0.0000 & 0.0000 & 0.0000 & 0.0000 & 0.0000 & 0.0000 \\
\hline sigma_u & 4.6799 & 3.3640 & 3.7842 & 4.2857 & 3.8846 & 3.7372 \\
\hline sigma_e & 1.5430 & 1.4915 & 1.7180 & 1.5796 & 1.4794 & 1.7341 \\
\hline rho & 0.9020 & 0.8357 & 0.8291 & 0.8804 & 0.8733 & 0.8228 \\
\hline
\end{tabular}

Standard errors clustered by reporter-partner are in parenthesis.

* $p<0.10,{ }^{* *} p<0.05,{ }^{* * *} p<0.01$

Fixed-effects dimension: reporter-partner $\left(\mu_{i j}\right)$. All regressions include time DVs $\left(a f 04\right.$ and $\left.\theta_{t}\right)$. 


\subsection{The trend of the commercial partner groups over time}

This complementary empirical exercise aims at overcoming the time issue that could not be addressed by the usual DID strategy. The DID strategy relies heavily on the definition of a temporal control group, which by construction, is defined as 1999-2003. Nevertheless, if entrance to the single market had an anticipated trade effect, the period 1999-2003 might not be an adequate control. In this exercise, we fix the initial year of the period (1999) as the reference point, and observe the variation in the intensity of trade flows between the EU10 and its commercial partners over time, using the ROW as the partner reference, as shown in Equation (6). In this way, we can confirm whether or not the results obtained from the DID strategy are consistent or sensitive to the definition of the temporal control group.

The results are presented graphically to summarize and favor their interpretation. The results of the regressions that consider all sectors jointly are illustrated in Figures 2 and 3, for exports and imports, respectively. These regressions were estimated using reporter-partnersector fixed effects $\left(\lambda_{i j s}\right)$. The graphs depict the values of the coefficients of interest over the period 2000-2011 $\left(\gamma_{e u 15}^{t}, \gamma_{e u 10}^{t}\right.$, and $\left.\gamma_{f s u}^{t}, t=2000, \ldots, 2011\right)$, as well as their confidence intervals at the five percent level. ${ }^{31}$ The sectoral analysis is included in Appendix B (Figures B.1-B.6). In this case, the fixed effects were at reporter-partner level $\left(\mu_{i j}\right)$.

We analyze the EU10's export flows to each commercial partner group separately (Figure 2). We find that from 2004 to 2010 there were differences between exports flows to the EU15 and those to the ROW (control group), evidenced by the positive and statistically significant coefficient $\gamma_{e u 15}^{t}$. The coefficient did not follow any specific trend; thus we can assume that the redirection of the EU10's export flows was an isolated event that occurred in the year of the fifth EU enlargement (2004). ${ }^{32}$ Appendix B (Figure B.1) shows the same conclusions for chemicals and F\&B sectors, but a negative or null effect for all other sectors. These results support the heterogeneous behavior in the variation of the intensity of the EU10's export flows to the EU15 previously detected. We find exports to the EU10 increased more than those to the ROW from 2006 to 2011 , evidenced by the positive and statistically significant coefficient $\widehat{\gamma}_{e u 10}^{t}$. In contrast, the coefficient $\widehat{\gamma}_{f s u}^{t}$ was negative and statistically significant from 2001 to 2004, suggesting that there was export redirection from the FSU to the ROW prior to the fifth EU enlargement. At the sectoral level this pattern is also found in the chemicals sector (Appendix B, Figure B.3).

\footnotetext{
${ }^{31} \mathrm{~A}$ coefficient is statistically significant if the range of its confidence interval does not contain the value zero. Graphically this means that the horizontal line $y=0$ does not cross the confidence interval, which is represented in grey.

${ }^{32}$ The variation between two consecutive coefficients was not statistically different from zero except between 2008 and 2009, when negative changes were caused by economic crisis.
} 
This outcome encourages us to refine the conclusions reported in the previous subsection, where we find that the fifth EU enlargement did not impact the intensity of the EU10's exports to the FSU.

Finally, we examine the EU10's import flows (Figure 3). We find that from 2004 to 2011, imports from the EU15 increased more than those from the ROW, evidenced by the positive and statistically significant coefficient $\widehat{\gamma}_{e u 15}^{t}$. In this case, trade redirection was not isolated; we identify a positive trend from 2003 to 2006 and from 2008 to $2010 .{ }^{33}$ Meanwhile, the coefficient $\widehat{\gamma}_{e u 10}^{t}$ was positive and statistically significant from 2004 to 2011, following a slight positive trend (except from 2006 to 2007, where it was constant). In Appendix B (Figure B.5), we present evidence for the existence of a positive change from 2003 to 2004 for all sectors. The coefficient $\widehat{\gamma}_{f s u}^{t}$ was positive and statistically significant from 2005 to 2011 (except in 2009), a pattern that is also found in the F\&B sector (Appendix B, Figure B.6).

We can highlight several interesting findings resulting from this second empirical exercise. For one, we can confirm that the redirection of the EU10's exports from the ROW to the EU15 was an isolated event occurring in a few sectors in 2004. We also find a negative change of the intensity of exports to the FSU immediately prior to the official entry of the EU10 into the EU. Additionally, we find a huge variation of the intensity of the EU10's import flows from the EU10 from 2003 to 2004 in all sectors. ${ }^{34}$ Unlike the DID strategy, this technique shows the trend of each commercial partner group during the entire period, using 1999 as the reference. In general, the effects on the EU10's imports were stronger than those on their exports.

\footnotetext{
${ }^{33}$ This means that the variation between two consecutive coefficients was positive and statistically significant.

${ }^{34}$ The coefficient $\widehat{\gamma}_{e u 10}^{t}$ was statistically different from $\widehat{\gamma}_{e u 15}^{t}$ in all sectors except F\&B. In Appendix B, Figure B.4 shows the trend of the latter coefficient over time and Figure B.5 shows the same for the former coefficient.
} 
Figure 2: Trend of the commercial partner DVs over time (EU10's exports)

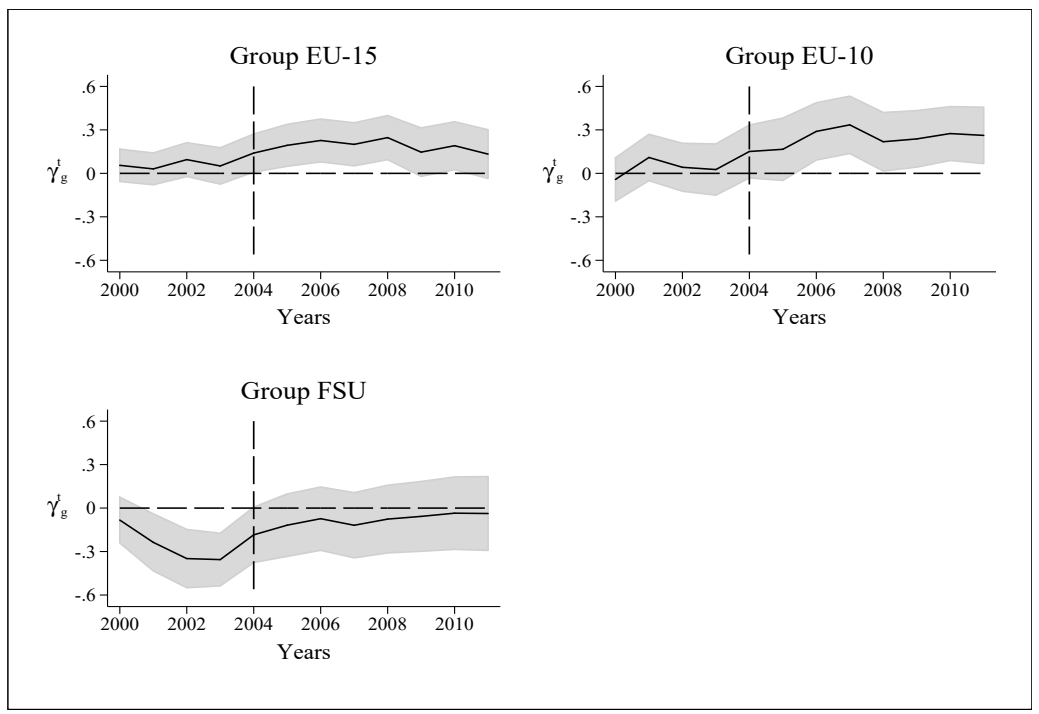

Figure 3: Trend of the commercial partner DVs over time (EU10's imports)

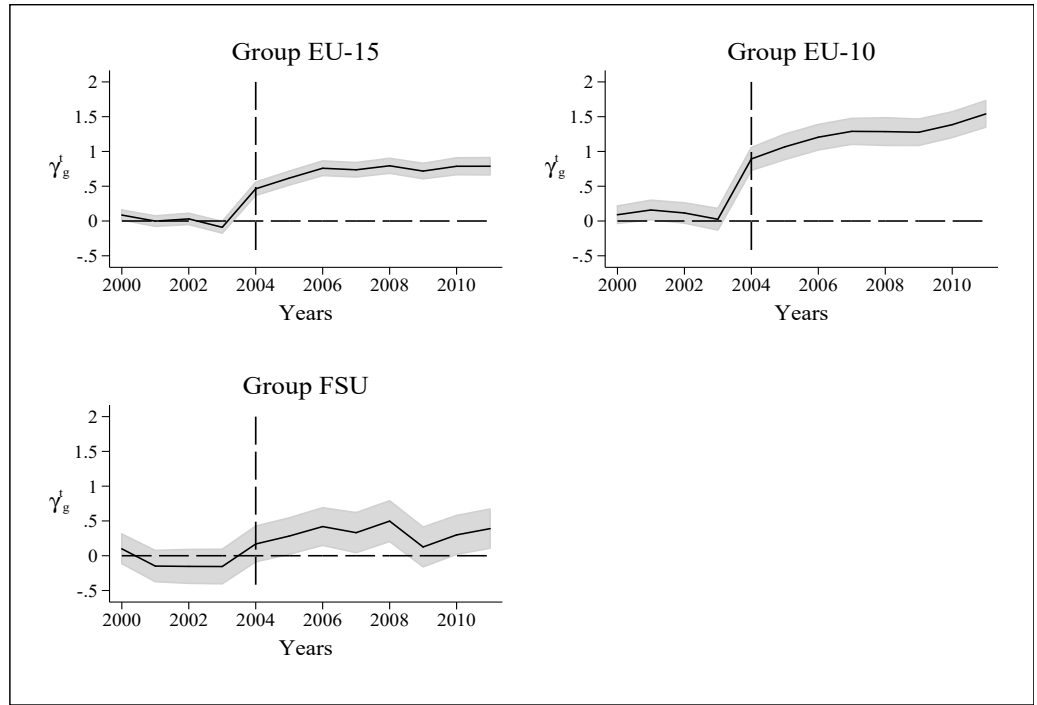




\section{Extensions}

In this section, we implement two additional exercises to check the consistency of the results discussed in Section 5. In the former exercise, we deal with the missing values problem in a different way. Now, missing values are not excluded from the sample and they are replaced by zeroes. Then, an alternative estimator method is implemented in order to deal with the large number of zero values. In the latter exercise, an additional explanatory variable is included in the baseline econometric specification (3).

Although one of the most important concerns of the trade flow literature is how to deal with missing values and zeroes, there is not a consensus about how to handle this important issue. In some studies, missing values are treated as zeroes (Gleditsch, 2002; Brun et al., 2005; Felbermayr and Kohler, 2006; and Coe et al., 2007), while others insists that these values are conceptually different (Harris et al., 2012). In Sections 4 and 5 we addressed the zero values problem by adding one unit to the trade flow data before taking logarithms (Chen, 2004), while missing values were excluded from the sample. Nevertheless, excluding the missing observations is not riskless. Gleditsch (2002) discusses and demonstrates that the removal of missing values could lead to non-random samples that produces misleading inferences and results. King et al. (2001) confirm that the consequences from the missing values can be worse than those from the omitted variable bias problem. Gleditsch (2002) proposes several procedures to solve the problem, one among others to replace the missing values by zeroes. He argues that when a trade flow data reported by two commercial partners are missing, it means that the intensity of trade flows among these countries is expected to be small or negligible. Following this reasoning, as a first robustness check, we assume the most extreme working hypothesis and we consider that a missing value is equal to a zero value. In this way, it is possible to test whether or not excluding missing values created a biased sample.

When equalizing missing values to zero values, we need to face the necessity of finding a robust estimator for a sample where the dependent variable has a high proportion of zeroes. The literature suggests exploiting the Poisson distribution (Santos Silva and Tenreyro, 2006), which is usually implemented in count data models, where the dependent variable can take nonnegative values (zeros and positive values). In our case, the value of the exports (or imports) is the response variable. The Poisson regression shapes the logarithm of the expected count as a function of a group of selected explanatory variables. For instance, the coefficient $\gamma_{g}^{a f 04}$ of Equation (4) indicates the difference (in units) in the logarithms of the expected counts 
between group $g$ and the ROW after 2004 (assuming that the other variables are constant). Following Westerlund and Wilhelmsson (2011) we implemented a FE Poisson ML estimator. This model allows us to correct not only for the zero values (or missing values) but also for the heteroskedaticity inherent in log-linearized models (Santos Silva and Tenreyro, 2006).

Because the coefficients reported by the FE Poisson ML model are not directly comparable with those obtained from the FE model (Tables 1-4), we focus primarily on the significance of the coefficients of interest without making cross comparisons. Table 5 shows the results for all sectors jointly; column 1 for the exports and column 2 for the imports. Among exports, the coefficients $\widehat{\gamma}_{e u 15}^{a f 04}$ and $\widehat{\gamma}_{e u 10}^{a f 04}$ were not statistically different from zero while they were in the FE model (Table 1, column 3). Among imports, these coefficients were statistically significant at the one percent level as they were in the FE model (Table 3, column 3). This new estimator confirms that there was a redirection of the EU10's imports from the ROW to the EU markets after 2004, above all toward the EU10 market.

We use the sectoral analysis to check the validity of our results at a more disaggregated level (see Table 6 for exports and Table 7 for the imports by sector). Among exports, some of the results were consistent with those found in the FE model (Table 2). For instance, the coefficient $\widehat{\gamma}_{e u 15}^{a f 04}$ was positive in two of the sectors sectors and negative in three. Among imports (Table 7), the coefficients $\widehat{\gamma}_{e u 15}^{a f 04}$ and $\widehat{\gamma}_{e u 10}^{a f 04}$ were positive and statistically significant for four and five sectors, respectively. ${ }^{35}$ Then, we can declare that our main results are robust to the implementation of another estimator method that handles the problem of the missing and zero values.

\footnotetext{
${ }^{35}$ Table 7 does not report results for the machinery and vehicles sector because the FE Poisson ML estimator did not converge. We attempt to fix this technical problem by following the suggestions of Santos Silva and Tenreyro (2011), but unfortunately they did not apply to our case because we have a panel of data. One of the possible sources of the problem is the existence of perfect collinearity between regressors in the sample where the dependent variable (the imports) is positive.
} 
Table 5: EU10's trade flows (all sectors)

\begin{tabular}{lcc}
\hline \hline Estimator: & \multicolumn{2}{c}{ FE Poisson ML } \\
\cline { 2 - 3 } Dependent variable: & $(1)$ & $(2)$ \\
exports $_{i j s t}$ & imports $_{i j s t}$ \\
\hline lnGDP $_{i t}$ & $0.5649^{* * *}$ & $0.6773^{* * *}$ \\
& $(0.1138)$ & $(0.1072)$ \\
$\operatorname{lnGDP}_{j t}$ & $0.7418^{* * *}$ & $0.5635^{* * *}$ \\
& $(0.0730)$ & $(0.0731)$ \\
eu15 $_{\text {af04 }}$ & -0.0392 & $0.2694^{* * *}$ \\
& $(0.0538)$ & $(0.0617)$ \\
eu10 & 0.0328 & $0.4541^{* * *}$ \\
& $(0.0613)$ & $(0.0736)$ \\
fsu $_{a f 04}$ & -0.0269 & -0.1132 \\
& $(0.0833)$ & $(0.0953)$ \\
\hline Observations & 120694 & 115362 \\
Wald & 4384.4776 & 5251.6186 \\
pvalue & 0.0000 & 0.0000 \\
iterations & 5 & 4 \\
\hline \hline
\end{tabular}

SEs clustered by reporter-partner-sector are in parenthesis.

$* p<0.10,{ }^{* *} p<0.05,{ }^{* * *} p<0.01$

Fixed-effects dimension: reporter-partner-sector $\left(\lambda_{i j s}\right)$.

All regressions include time DVs (af04 and $\left.\theta_{t}\right)$. 
Table 6: EU10's export flows (by sector)

\begin{tabular}{|c|c|c|c|c|c|c|}
\hline & \multicolumn{6}{|c|}{ Dependent variable: exports ${ }_{i j t}$ - Estimator: FE Poisson ML } \\
\hline & Chemicals & $\mathrm{F} \& \mathrm{~B}$ & Machinery & Manufbymat & Othermanuf & Rawmat \\
\hline \multirow[t]{2}{*}{$\ln \mathrm{GDP}_{i t}$} & 0.1806 & $0.5265^{* *}$ & $0.9590^{* * *}$ & 0.0861 & $0.7211^{* * *}$ & -0.2336 \\
\hline & $(0.1814)$ & $(0.2455)$ & $(0.1945)$ & $(0.0943)$ & $(0.1701)$ & $(0.2098)$ \\
\hline \multirow{2}{*}{$\operatorname{lnGDP}_{j t}$} & $0.2161^{*}$ & $0.2968^{*}$ & $0.9587^{* * *}$ & $0.5908^{* * *}$ & $0.8559^{* * *}$ & $0.7641^{* * *}$ \\
\hline & $(0.1116)$ & $(0.1635)$ & $(0.1351)$ & $(0.1016)$ & $(0.1084)$ & $(0.1611)$ \\
\hline \multirow[t]{2}{*}{ eu15af04 } & $0.2161^{* *}$ & $0.7565^{* * *}$ & -0.1015 & 0.0680 & $-0.1603^{* *}$ & $-0.4700^{* *}$ \\
\hline & $(0.0897)$ & $(0.1179)$ & $(0.0927)$ & $(0.0609)$ & $(0.0765)$ & $(0.2332)$ \\
\hline \multirow[t]{2}{*}{ eu10 $0_{a f 04}$} & 0.0698 & $0.6165^{* * *}$ & 0.1196 & $0.1388^{*}$ & 0.0777 & $-0.3966^{*}$ \\
\hline & $(0.0899)$ & $(0.1268)$ & $(0.1270)$ & $(0.0757)$ & $(0.0975)$ & $(0.2293)$ \\
\hline \multirow[t]{2}{*}{$\mathrm{fsu}_{a f 04}$} & $0.3874^{* * *}$ & 0.2067 & 0.0826 & $0.1598^{*}$ & -0.2148 & $-0.7201^{* * *}$ \\
\hline & $(0.1104)$ & $(0.1609)$ & $(0.1506)$ & $(0.0928)$ & $(0.1466)$ & $(0.2602)$ \\
\hline Observations & 20334 & 19341 & 21703 & 20667 & 21132 & 17517 \\
\hline Number of groups & 1576 & 1498 & 1682 & 1602 & 1638 & 1357 \\
\hline Wald & 1700.1019 & 872.8663 & 2835.5171 & 7087.0012 & 1650.1746 & 1448.2662 \\
\hline pvalue & 0.0000 & 0.0000 & 0.0000 & 0.0000 & 0.0000 & 0.0000 \\
\hline iterations & 5 & 4 & 5 & 4 & 4 & 4 \\
\hline
\end{tabular}

Standard errors clustered by reporter-partner are in parenthesis.

${ }^{*} p<0.10,{ }^{* *} p<0.05,{ }^{* * *} p<0.01$

Fixed-effects dimension: reporter-partner $\left(\mu_{i j}\right)$. All regressions include time DVs $\left(a f 04\right.$ and $\left.\theta_{t}\right)$. 
Table 7: EU10's import flows (by sector)

\begin{tabular}{|c|c|c|c|c|c|}
\hline & \multicolumn{5}{|c|}{ Dependent variable: imports ${ }_{i j t}$ - Estimator: FE Poisson ML } \\
\hline & Chemicals & $\mathrm{F} \& \mathrm{~B}$ & Manufbymat & Othermanuf & Rawmat \\
\hline \multirow[t]{2}{*}{$\operatorname{lnGDP}{ }_{i t}$} & $0.3471^{* * *}$ & $0.3294^{* *}$ & $0.6488^{* * *}$ & $1.0346^{* * *}$ & 0.0369 \\
\hline & $(0.0992)$ & $(0.1535)$ & $(0.1102)$ & $(0.1923)$ & $(0.2346)$ \\
\hline \multirow[t]{2}{*}{$\operatorname{lnGDP}_{j t}$} & $0.5173^{* * *}$ & $-0.2752^{*}$ & $0.4143^{* * *}$ & $0.3533^{* * *}$ & 0.0201 \\
\hline & $(0.1159)$ & $(0.1471)$ & $(0.0933)$ & $(0.1273)$ & $(0.1019)$ \\
\hline \multirow[t]{2}{*}{ eu15af04 } & $0.4523^{* * *}$ & $0.9735^{* * *}$ & 0.0738 & $0.3020^{* *}$ & $0.4522^{* *}$ \\
\hline & $(0.0965)$ & $(0.1352)$ & $(0.0881)$ & $(0.1457)$ & $(0.1775)$ \\
\hline \multirow[t]{2}{*}{$\mathrm{eu} 10_{a f 04}$} & $0.5355^{* * *}$ & $1.1665^{* * *}$ & $0.2000^{* *}$ & $0.5385^{* * *}$ & $0.5382^{* * *}$ \\
\hline & $(0.0986)$ & $(0.1356)$ & $(0.0984)$ & $(0.1056)$ & $(0.1883)$ \\
\hline \multirow[t]{2}{*}{$\mathrm{fsu}_{a f 04}$} & -0.0582 & $0.5862^{* * *}$ & $-0.2862^{*}$ & -0.1455 & 0.2843 \\
\hline & $(0.1140)$ & $(0.2049)$ & $(0.1678)$ & $(0.1411)$ & $(0.1779)$ \\
\hline Observations & 16538 & 19761 & 19486 & 20929 & 18381 \\
\hline Number of groups & 1281 & 1530 & 1510 & 1622 & 1421 \\
\hline Wald & 3357.1812 & 1443.2650 & 3558.8817 & 2696.3660 & 2624.6489 \\
\hline pvalue & 0.0000 & 0.0000 & 0.0000 & 0.0000 & 0.0000 \\
\hline iterations & 4 & 4 & 4. & 4 & 5 \\
\hline
\end{tabular}

Standard errors clustered by reporter-partner are in parenthesis.

${ }^{*} p<0.10,{ }^{* *} p<0.05,{ }^{* * *} p<0.01$

Fixed-effects dimension: reporter-partner $\left(\mu_{i j}\right)$.

All regressions include time DVs (af04 and $\theta_{t}$ ).

The estimator does not converge for machinery and vehicle sector. 
Finally, we propose another extension to study the effects on the coefficients of interest when we include other relevant explanatory variables, such as FDI, in the baseline specification (3). According to the economic literature, FDIs are considered complementary or substitutes for exports (Pantulu and Poon, 2003; Markusen, 2002). With this perspective, there is the possibility that the intensity and direction of the EU10's trade flows after 2004 could be associated with the potential entry or exit of FDIs in the EU10 countries. If FDIs and trade flows were complementary, more FDI from country $i$ to country $j$ would positively affect the exports from country $i$ to country $j$. On the contrary, if FDIs and trade flows were substitutes, more FDI from country $i$ to country $j$ would have a negative effect on the exports from country $i$ to country $j$.

We use FDI stock data, extracted from Eurostat's database EU direct investments - main indicators. ${ }^{36}$ These data capture the size of the foreign stock of capital in the host economy. ${ }^{37}$ In monetary terms, the EU10's inward FDI stocks were much more considerable than the EU10's outward FDI stocks. In 1999, the EU10's inward FDI stock represented 300, 510 million euros and their outward FDI stock represented 144,150 million euros. This difference sharply increased in 2011; inward FDI stock represented 2,446,158 million euros and outward FDI stock represented 159, 462 million euros. Table 8 tabulates the EU10's inward FDI stock. The main investor in the EU10 market was the EU15, representing around 80 percent of the total FDI. According to Lipsey (2006), the CEECs became one of the major locations for FDI from Europe, particularly from Germany, starting in 1990.

Table 8: EU10's inward FDI stock (1999 and 2011)

\begin{tabular}{rrrrr}
\hline \hline & \multicolumn{2}{c}{ Year 1999 } & \multicolumn{2}{c}{ Year 2011 } \\
investor & Million euros & \multicolumn{1}{c}{$\%$} & Million euros & \multicolumn{1}{c}{$\%$} \\
\hline EU15 & 243,288 & 80.96 & $1,961,172$ & 80.17 \\
EU10 & 6,696 & 2.23 & 171,288 & 7.00 \\
FSU & 1,350 & 0.45 & 19,806 & 0.81 \\
ROW & 49,176 & 16.36 & 293,892 & 12.01 \\
\hline Total & 300,510 & & $2,446,158$ \\
\hline \hline
\end{tabular}

Own elaboration based on data from Eurostat.

\footnotetext{
${ }^{36}$ Available at http://epp.eurostat.ec.europa.eu/portal/page/portal/balance_of_payments/data/database

${ }^{37}$ The FDI stocks are measured according the value of the foreign investment at the end of the period.
} 
The econometric specification for this extension becomes an augmented version of baseline econometric specification (3):

$$
\begin{aligned}
\ln T_{i j s t}= & \beta_{0}+\beta_{1} \ln G D P_{i t}+\beta_{2} \ln G D P_{j t}+\beta_{3} \ln F D I_{i j t}^{d}+ \\
& +\gamma_{\text {eu15 }}^{a f 04} e u 15_{a f 04}+\gamma_{e u 10}^{a f 04} e u 10_{a f 04}+\gamma_{f s u}^{a f 04} f s u_{a f 04}+a f 04+\lambda_{i j s}+\theta_{t}+\varepsilon_{i j s t} \\
& i=1, \ldots, 10, j=1, \ldots 180(i \neq j), s=1, \ldots, 6, t=1999, \ldots 2011
\end{aligned}
$$

where $d$ represents outward stocks when the dependent variable describes export flows, and $d$ represents inward stocks when the dependent variable describes import flows. Unfortunately, FDI information is not disaggregated at the sector level, so we can capture only bilateral relations between countries. Focusing on exports we control for the logarithm of the investment that country $i$ holds in country $j$ at the end of year $t\left(\ln F D I_{i j t}^{\text {outward }}\right)$. When treating imports, we control for the logarithm of investment that country $j$ holds in country $i$ at the end of year $t$ $\left(\ln F D I_{i j t}^{\text {inward }}\right) .{ }^{38}$

The results are presented as follows: Table 9 considers all sectors jointly, column 1 for exports and column 2 for imports; Table 10 reports the exports by sector; and Table 11 reports the imports by sector. In all cases, the coefficient $\widehat{\beta}_{3}$ was not statistically different from zero. Though $F D I_{i j t}^{d}$ is a time-variant variable, its variability seems to be captured by the country-pair fixed effects. We can also see that after the inclusion of this new regressor, the significance of our variables of interest did not change; in only a few of cases the magnitudes of the coefficients slightly decreased. Hence, we can declare that our results are robust to the inclusion of bilateral FDI data.

\footnotetext{
${ }^{38}$ Following the strategy implemented in Sections 4 and 5 , we address the zero values problem by adding one unit to the trade flow data before taking logarithms (Chen, 2004), while missing values are excluded from the sample (Harris et al., 2012).
} 
Table 9: EU10's trade flows (all sectors)

\begin{tabular}{|c|c|c|}
\hline \multirow[t]{2}{*}{ Estimator: } & \multicolumn{2}{|c|}{$\mathrm{FE}$} \\
\hline & (1) & $(2)$ \\
\hline Dependent variable: & $\ln \left(\right.$ exports $\left._{i j s t}+1\right)$ & $\ln \left(\operatorname{imports}_{i j s t}+1\right)$ \\
\hline \multirow[t]{2}{*}{$\operatorname{lnGDP} i t$} & $0.9163^{* * *}$ & $0.9966^{* * *}$ \\
\hline & $(0.1156)$ & $(0.1495)$ \\
\hline \multirow[t]{2}{*}{$\operatorname{lnGDP}_{j t}$} & $0.6798 * * *$ & $0.2126^{* * *}$ \\
\hline & $(0.0672)$ & $(0.0792)$ \\
\hline \multirow{2}{*}{$\operatorname{lnFDI} I_{i j t}^{\text {outward }}$} & -0.0003 & \\
\hline & $(0.0013)$ & \\
\hline \multirow[t]{2}{*}{$\operatorname{lnFDI} I_{i j t}^{i n w a r d}$} & & -0.0036 \\
\hline & & $(0.0027)$ \\
\hline \multirow[t]{2}{*}{ eu15 $a f 04$} & $0.1368^{* * *}$ & $0.5910^{* * *}$ \\
\hline & $(0.0502)$ & $(0.0545)$ \\
\hline \multirow[t]{2}{*}{ eu10 $10_{a f 04}$} & $0.1640^{* *}$ & $1.0603^{* * *}$ \\
\hline & $(0.0642)$ & $(0.0963)$ \\
\hline \multirow[t]{2}{*}{$\mathrm{fsu}_{a f 04}$} & 0.0571 & $0.3640^{* * *}$ \\
\hline & $(0.0893)$ & $(0.0899)$ \\
\hline \multirow[t]{2}{*}{ constant } & $-26.0340^{* * *}$ & $-16.2332^{* * *}$ \\
\hline & $(3.2588)$ & $(4.0537)$ \\
\hline Observations & 59098 & 52264 \\
\hline Number of groups & 8911 & 7980 \\
\hline R-sq(overall) & 0.3689 & 0.1949 \\
\hline R-sq(between) & 0.4053 & 0.1760 \\
\hline R-sq(within) & 0.1462 & 0.0503 \\
\hline $\mathrm{F}$ & 175.1592 & 80.4853 \\
\hline pvalue & 0.0000 & 0.0000 \\
\hline
\end{tabular}

Standard errors clustered by reporter-partner are in parenthesis.

$* p<0.10, * * p<0.05, * * * p<0.01$

Fixed-effects dimension: reporter-partner-sector $\left(\lambda_{i j s}\right)$.

All regressions include time DVs $\left(a f 04\right.$ and $\left.\theta_{t}\right)$. 
Table 10: EU10's export flows (by sector)

\begin{tabular}{|c|c|c|c|c|c|c|}
\hline & \multicolumn{6}{|c|}{ Dependent variable: $\ln \left(\operatorname{exports}_{i j t}+1\right)$ - Estimator: FE } \\
\hline & Chemicals & $\mathrm{F} \& \mathrm{~B}$ & Machinery & Manufbymat & Othermanuf & Rawmat \\
\hline \multirow[t]{2}{*}{$\operatorname{lnGDP} i t$} & $0.7045^{* * *}$ & $0.5391^{*}$ & $1.8612^{* * *}$ & 0.2763 & $1.1488^{* * *}$ & 0.3444 \\
\hline & $(0.2250)$ & $(0.3041)$ & $(0.1910)$ & $(0.2300)$ & $(0.2279)$ & $(0.3107)$ \\
\hline \multirow[t]{2}{*}{$\operatorname{lnGDP}_{j t}$} & $0.6082^{* * *}$ & $0.3081^{*}$ & $0.8600^{* * *}$ & $0.6283^{* * *}$ & $0.7721^{* * *}$ & $0.8657^{* * *}$ \\
\hline & $(0.1182)$ & $(0.1717)$ & $(0.1144)$ & $(0.1331)$ & $(0.1251)$ & $(0.1562)$ \\
\hline \multirow[t]{2}{*}{$\operatorname{lnFDI} I_{i j t}^{\text {outward }}$} & -0.0012 & -0.0029 & 0.0009 & 0.0041 & -0.0016 & -0.0009 \\
\hline & $(0.0027)$ & $(0.0038)$ & $(0.0026)$ & $(0.0026)$ & $(0.0022)$ & $(0.0031)$ \\
\hline \multirow[t]{2}{*}{ eu15 $a f 04$} & $0.5285^{* * *}$ & $1.2577^{* * *}$ & $-0.2270^{* * *}$ & $0.2234^{* * *}$ & $-0.3696^{* * *}$ & $-0.5646^{* * *}$ \\
\hline & $(0.1064)$ & $(0.1363)$ & $(0.0839)$ & $(0.0839)$ & $(0.0884)$ & $(0.1273)$ \\
\hline \multirow[t]{2}{*}{$\mathrm{eu} 10_{a f 04}$} & 0.1972 & $0.7487^{* * *}$ & -0.1322 & $0.5315^{* * *}$ & $-0.2009 * *$ & -0.1014 \\
\hline & $(0.1198)$ & $(0.1676)$ & $(0.1041)$ & $(0.1186)$ & $(0.1001)$ & $(0.1650)$ \\
\hline \multirow[t]{2}{*}{$\mathrm{fsu}_{a f 04}$} & $0.3588^{* * *}$ & $0.3921^{* *}$ & 0.0810 & $0.4897^{* * *}$ & $-0.3079^{* *}$ & $-0.6566^{* * *}$ \\
\hline & $(0.1369)$ & $(0.1914)$ & $(0.1583)$ & $(0.1699)$ & $(0.1537)$ & $(0.2283)$ \\
\hline \multirow[t]{2}{*}{ constant } & $-19.3271^{* * *}$ & -7.9886 & $-52.2712^{* * *}$ & -9.0323 & $-34.3097^{* * *}$ & $-17.7407^{* *}$ \\
\hline & $(6.2999)$ & $(8.3203)$ & $(5.3130)$ & $(6.6637)$ & $(6.1588)$ & $(7.9633)$ \\
\hline Observations & 9953 & 8629 & 11201 & 10370 & 10787 & 8158 \\
\hline Number of groups & 1505 & 1397 & 1625 & 1532 & 1581 & 1271 \\
\hline R-sq (overall) & 0.3842 & 0.2718 & 0.5159 & 0.4153 & 0.4149 & 0.2271 \\
\hline R-sq (between) & 0.4259 & 0.2685 & 0.5467 & 0.4723 & 0.4602 & 0.2329 \\
\hline R-sq (within) & 0.1738 & 0.1076 & 0.2696 & 0.0664 & 0.1617 & 0.1942 \\
\hline $\mathrm{F}$ & 56.6287 & 30.1166 & 102.8110 & 26.4668 & 55.1624 & 43.9197 \\
\hline pvalue & 0.0000 & 0.0000 & 0.0000 & 0.0000 & 0.0000 & 0.0000 \\
\hline
\end{tabular}

Standard errors clustered by reporter-partner are in parenthesis.

${ }^{*} p<0.10,{ }^{* *} p<0.05,{ }^{* * *} p<0.01$

Fixed-effects dimension: reporter-partner $\left(\mu_{i j}\right)$. All regressions include time DVs (af04 and $\left.\theta_{t}\right)$. 
Table 11: EU10's import flows (by sector)

\begin{tabular}{|c|c|c|c|c|c|c|}
\hline & \multicolumn{6}{|c|}{ Dependent variable: $\ln \left(\right.$ imports $\left._{i j t}+1\right)$ - Estimator: $\mathrm{FE}$} \\
\hline & Chemicals & $\mathrm{F} \& \mathrm{~B}$ & Machinery & Manufbymat & Othermanuf & Rawmat \\
\hline \multirow[t]{2}{*}{$\operatorname{lnGDP}_{i t}$} & -0.1969 & $0.9539^{* * *}$ & $1.5514^{* * *}$ & $1.2707^{* * *}$ & $1.4440^{* * *}$ & $0.6928^{* *}$ \\
\hline & $(0.3067)$ & $(0.2871)$ & $(0.2648)$ & $(0.2552)$ & $(0.2439)$ & $(0.3298)$ \\
\hline \multirow[t]{2}{*}{$\operatorname{lnGDP}_{j t}$} & -0.1087 & 0.1251 & $0.9631^{* * *}$ & 0.0969 & $0.2668^{* *}$ & -0.1325 \\
\hline & $(0.1816)$ & $(0.1454)$ & $(0.1537)$ & $(0.1538)$ & $(0.1343)$ & $(0.1823)$ \\
\hline \multirow[t]{2}{*}{$\operatorname{lnFDI} I_{i j t}^{\text {inward }}$} & -0.0074 & $-0.0123^{* *}$ & 0.0008 & -0.0002 & -0.0016 & -0.0025 \\
\hline & $(0.0070)$ & $(0.0059)$ & $(0.0053)$ & $(0.0054)$ & $(0.0046)$ & $(0.0077)$ \\
\hline \multirow[t]{2}{*}{ eu15 af 04} & $0.3729^{* * *}$ & $1.1906^{* * *}$ & $0.4140^{* * *}$ & $0.3281^{* * *}$ & $0.6340^{* * *}$ & $0.5127^{* * *}$ \\
\hline & $(0.1006)$ & $(0.0974)$ & $(0.0865)$ & $(0.0858)$ & $(0.0801)$ & $(0.1253)$ \\
\hline \multirow[t]{2}{*}{ eu10 ${ }_{a f 04}$} & $1.2898^{* * *}$ & $1.2713^{* * *}$ & $0.7497^{* * *}$ & $0.8750^{* * *}$ & $0.8979 * * *$ & $1.2129^{* * *}$ \\
\hline & $(0.1719)$ & $(0.1528)$ & $(0.1553)$ & $(0.1642)$ & $(0.1346)$ & $(0.1879)$ \\
\hline \multirow[t]{2}{*}{$\mathrm{fsu}_{a f 04}$} & $0.4543^{* *}$ & $0.7359^{* * *}$ & -0.2092 & 0.3435 & $0.4297^{* *}$ & $0.3914^{*}$ \\
\hline & $(0.2210)$ & $(0.1928)$ & $(0.1827)$ & $(0.2274)$ & $(0.2066)$ & $(0.2175)$ \\
\hline \multirow[t]{2}{*}{ constant } & $20.6052^{* *}$ & -12.5772 & $-47.7998 * * *$ & $-19.8707^{* * *}$ & $-28.9018^{* * *}$ & -0.5275 \\
\hline & $(8.2483)$ & $(7.8966)$ & $(7.8217)$ & $(7.3631)$ & $(6.8984)$ & $(8.8250)$ \\
\hline Observations & 7273 & 8965 & 9079 & 8798 & 10010 & 8139 \\
\hline Number of groups & 1092 & 1352 & 1425 & 1348 & 1508 & 1255 \\
\hline R-sq (overall) & 0.0230 & 0.1466 & 0.4203 & 0.0759 & 0.1936 & 0.0237 \\
\hline R-sq (between) & 0.1039 & 0.1349 & 0.4268 & 0.0552 & 0.1545 & 0.0047 \\
\hline R-sq (within) & 0.0862 & 0.0649 & 0.0710 & 0.0488 & 0.0476 & 0.0507 \\
\hline $\mathrm{F}$ & 26.6196 & 28.6910 & 30.4926 & 26.0563 & 27.2791 & 19.3360 \\
\hline pvalue & 0.0000 & 0.0000 & 0.0000 & 0.0000 & 0.0000 & 0.0000 \\
\hline
\end{tabular}

Standard errors clustered by reporter-partner are in parenthesis.

${ }^{*} p<0.10,{ }^{* *} p<0.05,{ }^{* * *} p<0.01$

Fixed-effects dimension: reporter-partner $\left(\mu_{i j}\right)$. All regressions include time DVs $\left(a f 04\right.$ and $\left.\theta_{t}\right)$. 


\section{Conclusions}

The Eastern enlargement represented an important challenge for the EU. We propose an empirical analysis to evaluate the potential effects of the EU10's trade flows after the fifth EU enlargement in 2004. Our database contains information on bilateral trade flows (exports and imports) between EU10 countries and 180 partners, divided into six sectors during the period 1999-2011. Using the standard gravity model and estimating a DID specification we analyze how joining the EU has affected the intensity and direction of the EU10's trade flows.

We find three interesting results. First, we find that trade exchanges between the EU10 and EU15 intensified after 2004; however, this trade integration was not homogeneous across all sectors. For sectors that include goods of high technological worth (machinery and vehicles and other manufactured articles), the variation of intensity of the EU10's export flows to the EU15 decreased with respect to the reference group, the ROW. This result could suggest that the quality of the production of the EU10 members either does not always meet the preferences of the EU15 buyers or that the EU10 producers cannot compete with those of the EU15, causing the EU10 to search for new markets. Second, there was export redirection from the FSU to the ROW between 2001 and 2004, meaning that the past strong commercial connections between the EU10 and the FSU deteriorated before the official entry of the EU10 into the EU. Finally, we find that EU10 consumer demand was strongly biased toward EU10 products, and this pattern was a generalized effect that extended to almost all the sectors.

Therefore, we detect two reasons that could explain the lack of a complete trade integration between the EU10 and EU15 countries, one related to competitiveness and the other to preferences. It would be interesting to further investigate the reasons behind the previous arguments to design and implement public policies more suitable for achieving a deeper economic integration within the $\mathrm{EU}$ as a whole. It would also be reasonable to think of more suitable industrial policies to be implemented in the EU10 countries to foster their competitiveness in a few technologically-sensitive sectors jointly with a clear strategy to favor the diffusion of EU10 products into the rest of Europe, by promoting, for instance, trade facilities that reduce trade cost. 


\section{References}

Abraham, F. and J. Konings (1999). 'Does the opening of Central and Eastern Europe threaten employment in the west?'. The World Economy, 22(4), pp. 585-601.

Anderson, J. E. and E. van Wincoop (2003). 'Gravity with gravitas: A solution to the border puzzle'. The American Economic Review, 93(1), pp. 170-192.

Antimiani, A. and V. Costantini (2013). 'Trade performances and technology in the enlarged European Union'. Journal of Economic Studies, 40(3), pp. 355-389.

Baier, S. L. and J. H. Bergstrand (2007). 'Do free trade agreements actually increase members' international trade?". Journal of International Economics, 71(1), pp. 72-95.

Baldwin, R. and D. Taglioni (2006). Gravity for dummies and dummies for gravity equations. NBER Working Paper No. 12516. Cambridge, MA: NBER. Available online at: http://www.nber.org/papers/w12516.

Baldwin, R. and C. Wyplosz (2012). The Economics of European Integration. London: McGraw-Hill Higher Education.

Baltagi, B. H. (2008). Econometric Analysis of Panel Data. Chichester: John Wiley \& Sons, Ltd.

Baltagi, B. H., P. H. Egger, and M. Pfaffermayr (2003). 'A generalized design for bilateral trade flow models'. Economics Letters, 80(3), pp. 391-397.

Brenton, P. A. and D. Gros (1997). 'Trade reorientation and recovery in transition economies'. Oxford Review of Economic Policy, 13(2), pp. 65-76.

Brun, J.-F., C. Carrère, P. Guillaumont, and J. de Melo (2005). 'Has distance died? Evidence from a panel gravity model'. The World Bank Economic Review, 19(1), pp. 99-120.

Bussière, M., J. Fidrmuc, and B. Schnatz (2008). 'EU enlargement and trade integration: Lessons from a gravity model'. Review of Development Economics, 12(3), pp. 562-576.

Carrère, C. (2004). 'Revising the effects of regional trade agreements on trade flows with proper specification of the gravity model'. European Economic Review, 50(2), pp. 223247.

Chen, N. (2004). 'Intra-national versus international trade in the European Union: Why do national borders matter?'. Journal of International Economics, 63(1), pp. 93-118. 
Coe, D. T., A. Subramanian, and N. T. Tamirisa (2007). The missing globalization puzzle: Evidence of the declining importance of distance. IMF Working Paper No. 07/126. Washington, DC: IMF. Available online at: http://www.imf.org/external/pubs/ft/staffp/2007/01/coe.htm.

Combes, P.-Ph., T. Mayer, and J.-F. Thisse (2008). Economic Geography: The Integration of Regions and Nations. Princeton, NJ: Princeton University Press.

EC (2001). 'Enlargement of the European Union: An historic opportunity'. Enlargement Directorate General, European Commission, Luxembourg. Available online at: http://ec.europa.eu/enlargement/archives/pdf/press_corner/publications/corpus_en.pdf.

Egger, P. H. and M. Larch (2011). 'An assessment of the Europe Agreements' effects on bilateral trade, GDP, and welfare'. European Economic Review, 55(2), pp. 263-279.

Egger, P. H. and M. Pfaffermayr (2003). 'The proper panel econometric specification of the gravity equation: A three-way model with bilateral interaction effects'. Empirical Economics, 28(3), pp. 571-580.

Eurostat (2012). Compact guides: 'European Neighbourhood Policy - South countries. International trade in goods'. doi: 10.2785/33006. Eurostat (European Commission), Luxembourg.

Eurostat (2013). StatWebsite Eurostat website. Eurostat (European Commission), Luxembourg.

Faucompret, E., J. Konings, and H. Vandenbussche (1999). 'The integration of Central and Eastern Europe in the European Union: Trade and labour market adjustment'. Journal of World Trade, 33(6), pp. 121-145.

Feenstra, R. (2004). Advanced International Trade: Theory and Evidence. Princeton, NJ: Princeton University Press.

Felbermayr, G. J. and W. Kohler (2006). 'Exploiting the intensive and extensive margins of world trade'. Review of World Economics, 142(4), pp. 642-674.

Fontagné, L., M. Freudenberg, and M. Pajot (1999). 'Le potentiel d'échanges entre l'Union Européenne et les PECO. Un réexamen'. Revue Économique, 50(6), pp. 1139-1168.

Frankel, J. A. (1997). Regional Trading Blocs In the World Economic System. Washington, DC: Peterson Institute for International Economics. 
Gleditsch, K. S. (2002). 'Expanded trade and GDP data'. The Journal of Conflict Resolution, 46(5), pp. 712-724.

Glick, R. and A. K. Rose (2002). 'Does a currency union affect trade? The time-series evidence'. European Economic Review, 46 (6), pp. 1125-1151.

Gros, D. and A. Steinherr (1995). Winds of Change: Economic Transition in Central and Eastern Europe. Harlow: Longman (UK).

Guimarães, P. and P. Portugal (2010). 'A simple feasible procedure to fit models with highdimensional fixed effects'. The Stata Journal, 10(4), pp. 628-649.

Halvorsen, R. and R. Palmquist (1980). 'The interpretation of dummy variables in semilogarithmic equations'. The American Economic Review, 70(3), pp. 474-475.

Harris, M. N., L. Kónya, and L. Mátyás (2012). 'Some stylized facts about international trade flows'. Review of International Economics, 20(4), 781-792.

Head, K. and T. Mayer (2000). 'Non-Europe: The magnitude and causes of market fragmentation in the EU'. Weltwirtschaftliches Archiv, 136(5), pp. 284-314.

Head, K. and T. Mayer (2004). 'The empirics of agglomeration and trade'. In J. V. Henderson and J. F. Thisse (Eds.), Amsterdam: Handbook of Regional and Urban Economics, Volume 4, Chapter 59, pp. 2609-2669. Elsevier.

Head, K., T. Mayer, and J. Ries (2010). 'The erosion of colonial trade linkages after independence'. Jounal of International Economics, 81(1), pp. 1-14.

Herderschee, H. and Z. Qiao (2007). Impact of intra-European trade agreements, 1990-2005: Policy implications for the Western Balkans and Ukraine. IMF Working Paper No. 07/126. Washington, DC: IMF. Available online at: http://www.imf.org/external/pubs/cat/longres.aspx?sk=20974.0.

Hornok, C. (2010). 'Trade-enhancing EU enlargement and the resurgence of East-East tradet'. Focus on European Economic Integration, 3, pp. 79-94.

IMF (2012). World economic and financial surveys: World Economic Outlook database (WEO). IMF website. International Monetary Found, Washington, DC.

King, G., A. J. O'Connell, J. Honaker, and K. Scheve (2001). 'Analyzing incomplete political science data: An alternative algorithm for multiple imputation'. American Political Science Review, 95, pp. 49-69. 
Lipsey, R. E. (2006). Measuring the impacts of FDI in Central and Eastern Europe. NBER Working Paper No. 12808. Cambridge, MA: NBER. Available online at: http://www.nber.org/papers/w12808.

Markusen, J. R. (2002). Multinational Firms and the Theory of International Trade. Cambridge, MA: The MIT Press.

Mátyás, L. (1997). 'Proper econometric specification of the gravity model'. The World Economy, 20(3), pp. 363-368.

Mayer, T. and S. Zignago (2011). 'Notes on CEPII's distances measures: The GeoDist database'. CEPII Working Paper 2011-25. http://www.cepii.fr/anglaisgraph/bdd/distances.htm.

McCallum, J. (1995). 'National borders matter: Canada-U.S. regional trade patterns'. The American Economic Review, 85(3), pp. 615-623.

Nitsch, V. (2000). 'National borders and international trade: Evidence from the European Union’. Canadian Journal of Economics 33(4), pp. 1091-1105.

Noël, P. (2008). Beyond dependence: How to deal with Russia gas. ECFR/09. London: ECFR. Available online at: http://ecfr.eu/content/entry/russia_gas_policy_brief/.

Paas, T. (2003). Regional integration and international trade in the context of EU eastward enlargement. HWWA Discussion Paper No. 218: Hamburg. Hamburg: HWWA. Available online at: http://papers.ssrn.com/sol3/papers.cfm?abstract_id=381440.

Pantulu, J. and J. P. H. Poon (2003). 'Foreign direct investment and international trade: Evidence from the US and Japan'. Journal of Economic Geography, 3, pp. 241-259.

Rettman, A. (2007). 'EU and Russia tackle thorny issues at Samara summit'. euobserver. http://euobserver.com/foreign/24088.

Rose, A. K. and E. van Wincoop (2001). 'National money as a barrier to international trade: The real case for currency union'. The American Economic Review, 91(2), pp. 386-390.

Santos Silva, J. M. C. and S. Tenreyro (2006). 'The log of the gravity'. The Review of Economics and Statistics, 88(4), pp. 641-658.

Santos Silva, J. M. C. and S. Tenreyro (2011). poisson: Some convergence issues. Available online at: http://personal.lse.ac.uk/tenreyro/poisson.pdf.

Soloaga, I. and L. A. Winters (2001). 'Regionalism in the nineties: What effect on trade?'. The North American Journal of Economics and Finance, 12(1), pp. 1-29. 
Tinbergen, J. (1962). Shaping the World Economy. New York: The Twentieth Century Fund. UN (2006). 'Standard International Trade Classification. Revision 4'. Statistical Papers, Series M No. 34/Rev.4, Department of Economics and Social Affairs, United Nations, Geneva. Available online at: http://unstats.un.org/unsd/cr/registry/regcst.asp? $\mathrm{Cl}=28$.

Westerlund, J. and F. Wilhelmsson (2011). 'Estimating the gravity model without gravity using panel data'. Applied Economics, 43(6), pp. 641-649.

Wooldridge, J. M. (2006). Introductory Econometrics. Mason, OH: Thomson South-Western. 


\section{A Appendix}

Table A.1: The EU member states

\begin{tabular}{lccc}
\hline \multicolumn{1}{c}{ Country } & ISO 3-alpha & Year entry & EU subgroup \\
\hline Austria & AUT & 1995 & EU15 \\
Belgium & BEL & 1958 & EU15 \\
Cyprus & CYP & 2004 & EU10 \\
Czech Republic & CZE & 2004 & EU10 \\
Denmark & DNK & 1973 & EU15 \\
Estonia & EST & 2004 & EU10 \\
Finland & FIN & 1995 & EU15 \\
France & FRA & 1958 & EU15 \\
Germany & DEU & 1958 & EU15 \\
Greece & GRC & 1981 & EU15 \\
Hungary & HUN & 2004 & EU10 \\
Ireland & IRL & 1973 & EU15 \\
Italy & ITA & 1958 & EU15 \\
Latvia & LVA & 2004 & EU10 \\
Lithuania & LTU & 2004 & EU10 \\
Luxembourg & LUX & 1958 & EU15 \\
Malta & MLT & 2004 & EU10 \\
Netherlands & NLD & 1958 & EU15 \\
Poland & POL & 2004 & EU10 \\
Portugal & PRT & 1986 & EU15 \\
Slovakia & SVK & 2004 & EU10 \\
Slovenia & SVN & 2004 & EU10 \\
Spain & ESP & 1986 & EU15 \\
Sweden & SWE & 1995 & EU15 \\
United Kingdom & GBR & 1973 & EU15 \\
\hline
\end{tabular}


Table A.2: List of non-EU countries

Africa (52 countries):

Algeria, Angola, Benin, Bostwana, Burkina Faso, Burundi, Cameroon, Cape Verde, Central African Rep., Chad, Comoros, Democratic Rep. of Congo, Republic of Congo, Côte d' Ivoire, Djibouti, Egypt, Equatorial Guinea, Eritrea, Ethiopia, Gabon, Gambia, Ghana, Guinea, Guinea-Bissau, Kenya, Lesotho, Liberia, Lybian Arab Jamahiriya, Madagascar, Malawi, Mali, Mauritania, Mauritius, Morocco, Mozambique, Namibia, Niger, Nigeria, Rwanda, Sao Tome and Principe, Senegal, Seychelles, Sierra Leone, South Africa, Sudan, Swaziland, United Rep. of Tanzania, Togo, Tunisia, Uganda, Zambia, Zimbabwe

America (34 countries):

Antigua and Barbuda, Argentina, Bahamas, Barbados, Belize, Bolivia, Brazil, Canada, Chile, Colombia, Costa Rica, Dominica, Dominican Rep., Ecuador, El Salvador, Grenada, Guatemala, Guyana, Haiti, Honduras, Jamaica, Mexico, Nicaragua, Panama, Paraguay, Peru, St.Kitts and Newis, St. Lucia, St. Vicent and the Grenadines, Suriname, Trinidad and Tobago, United States of America, Uruguay, Venezuela

Asia (47 countries):

Afghanistan, *Armenia, *Azerbaijan, Bahrain, Bangladesh, Bhutan, Brunei Darussalam, Cambodia, China, *Georgia, Hong Kong, India, Indonesia, Islamic Rep. of Iran, Iraq, Israel, Japan, Jordan, *Kazakhstan, South Korea, Kuwait, *Kyrgyz Republic, Lao People's Democratic Republic, Lebanon, Malaysia, Maldives, Mongolia, Myanmar, Nepal, Oman, Pakistan, Philippines, Qatar,

*Russian Federation, Saudi Arabia, Singapore, Sri Lanka, Syrian Arab Rep., Taiwan, *Tajikistan, Thailand, Timor-Leste, ${ }^{*}$ Turkmenistan, United Arab Emirates, ${ }^{*}$ Uzbekistan, Vietnam, Yemen

Europe (12 countries):

Albania, *Belarus, Bosnia and Herzegovina, Croatia, Iceland, the Former Yugoslav Rep. of Macedonia, *Republic of Moldova, Norway, San Marino, Switzerland, Turkey, *Ukraine

Oceania (10 countries):

Australia, Fiji, Kiribati, New Zealand, Papua New Guinea, Samoa, Solom Islands, Tonga, Tuvalu, Vanuatu

*FSU countries: 12 members (without taking into account Estonia, Latvia, and Lithuania). 
Figure A.1: Sectoral analysis: EU10's export flows (1999-2011).
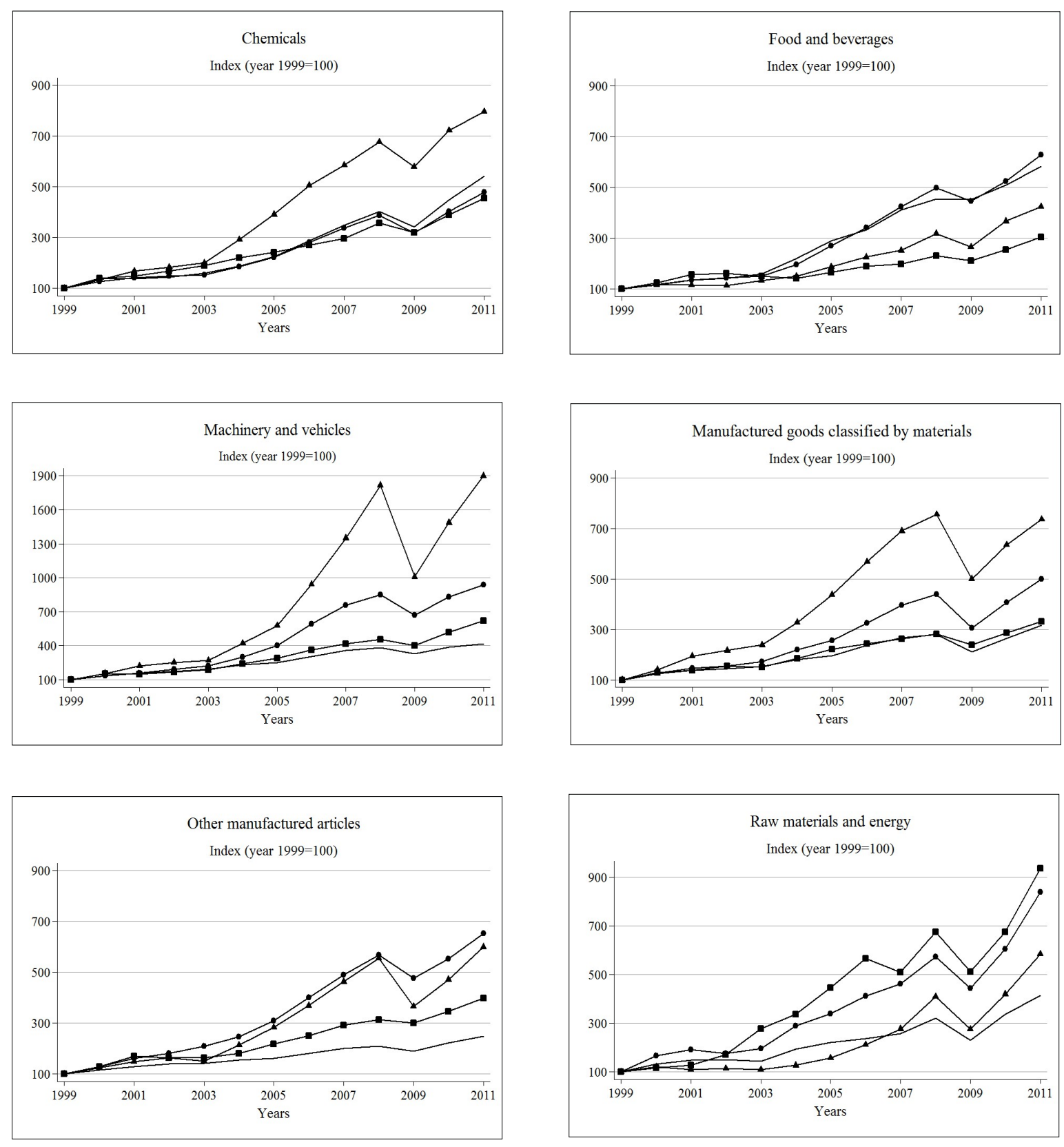

$\begin{array}{llllll} & \text { EU-15 } \longrightarrow \text { EU-10 } \longrightarrow \text { FSU } \rightarrow-\text { ROW }\end{array}$

Source: Own elaboration based on data from Eurostat. 
Figure A.2: Sectoral analysis: EU10's import flows (1999-2011).
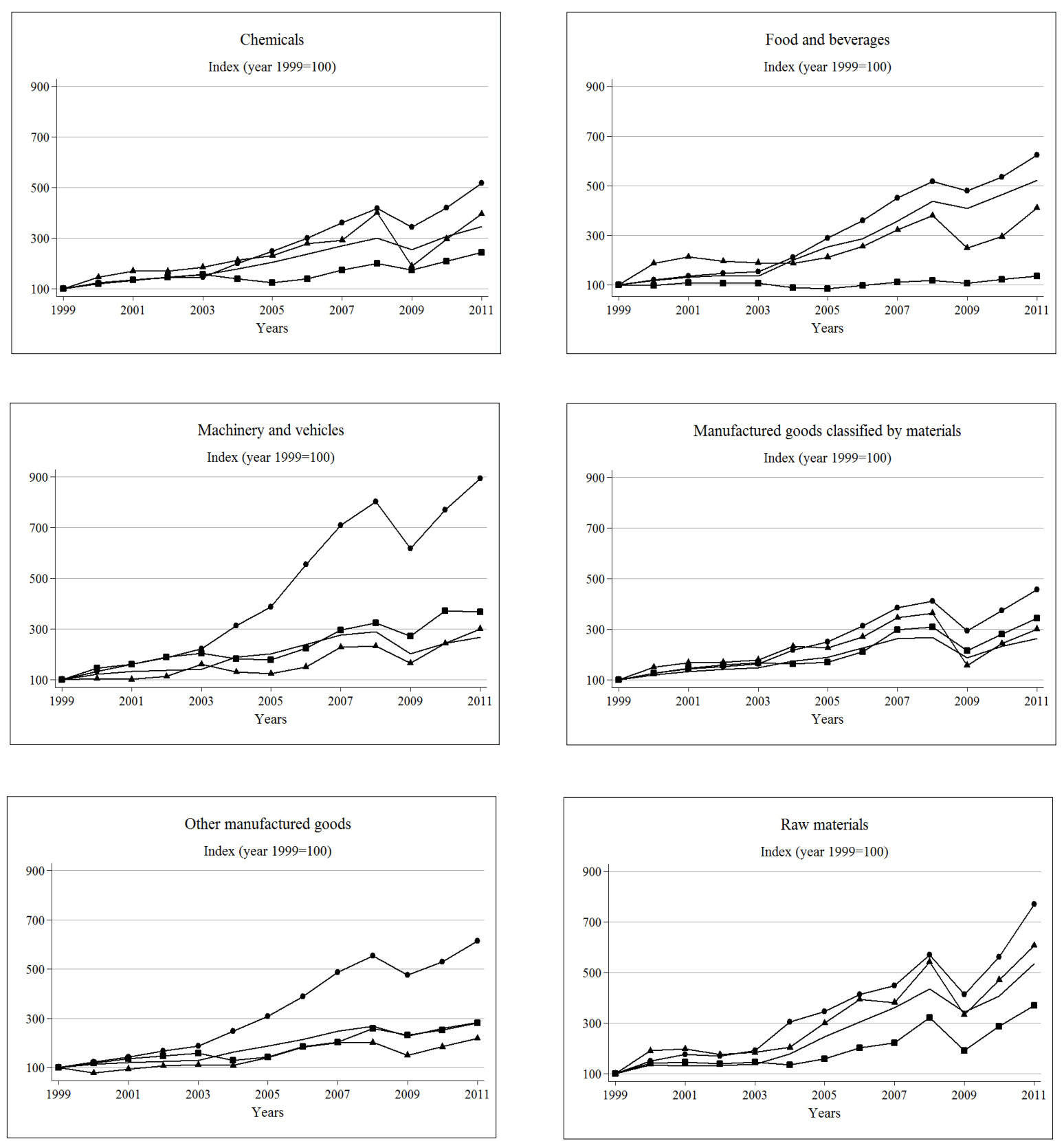

\section{$\longrightarrow$ EU-15 $-\quad$ EU-10 $\longrightarrow$ FSU $\longrightarrow-$ ROW}

Source: Own elaboration based on data from Eurostat. 


\section{B Appendix}

\section{B.1 Exports by sector: Trend of the commercial partner DVs over time}

Figure B.1: Group EU15

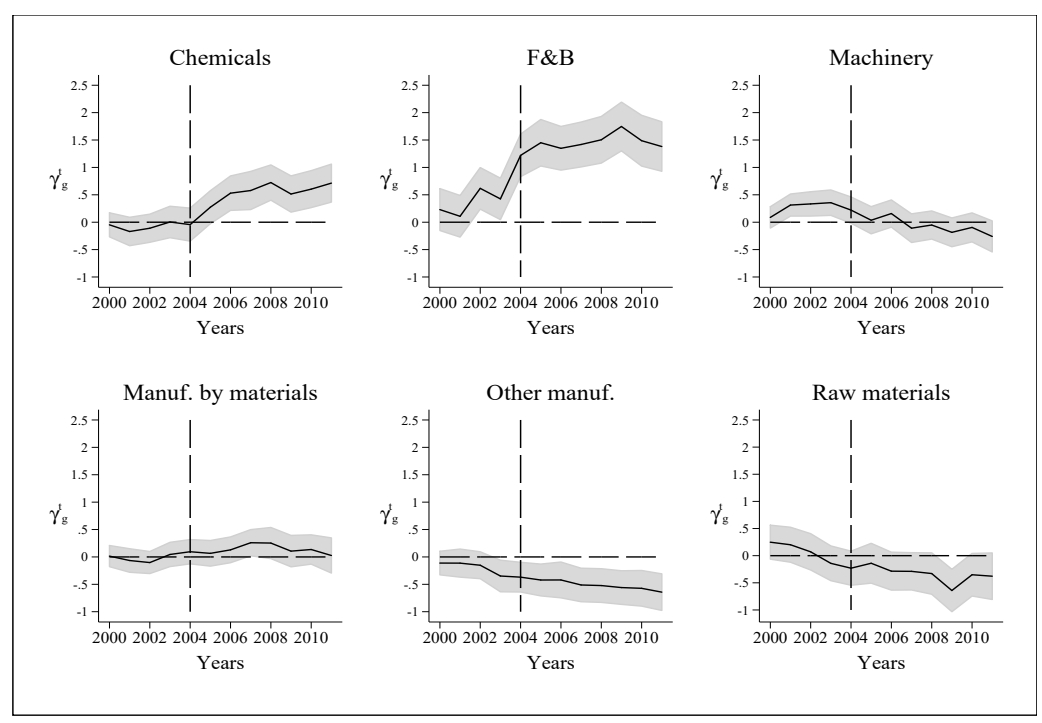

Figure B.2: Group EU10

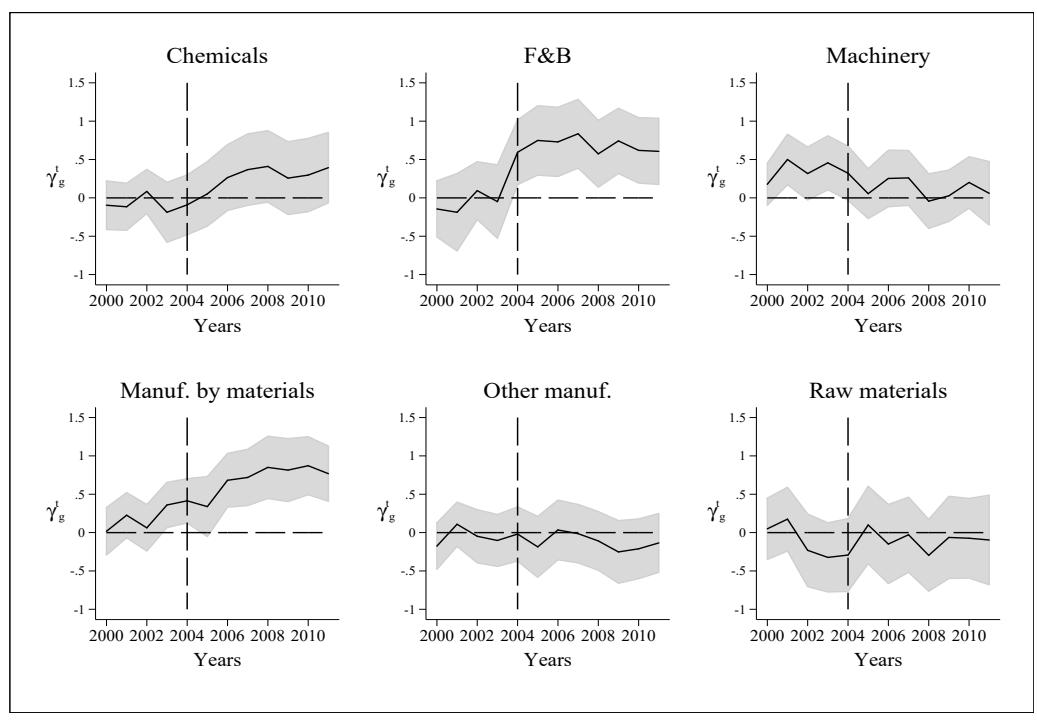


Figure B.3: Group FSU

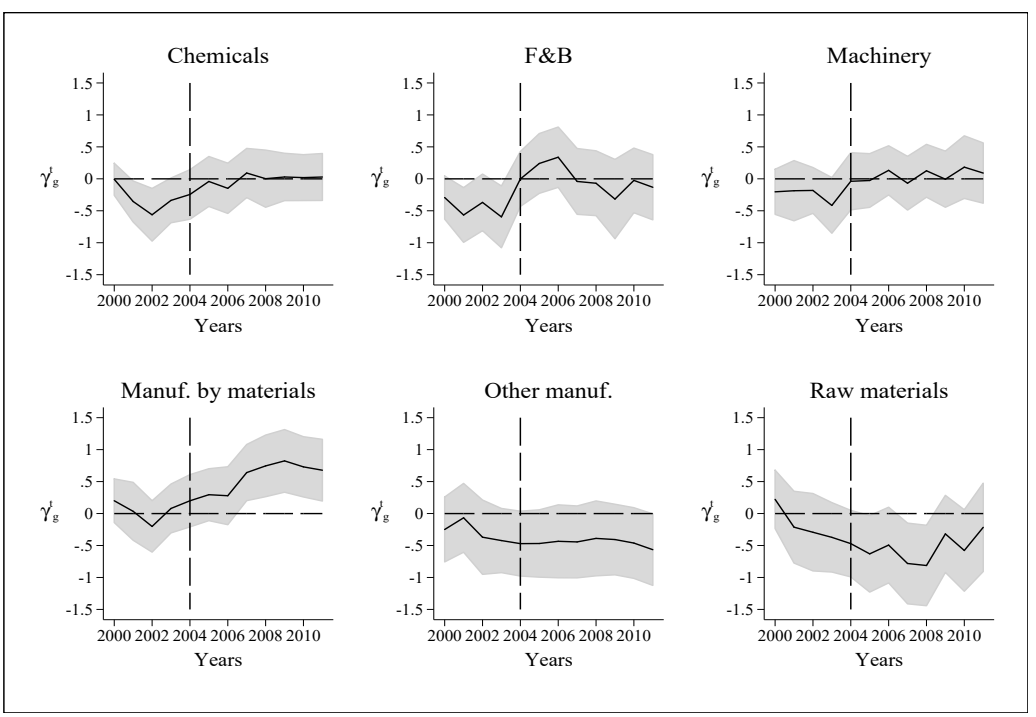

\section{B.2 Imports by sector: Trend of the commercial partner DVs over time}

Figure B.4: Group EU15

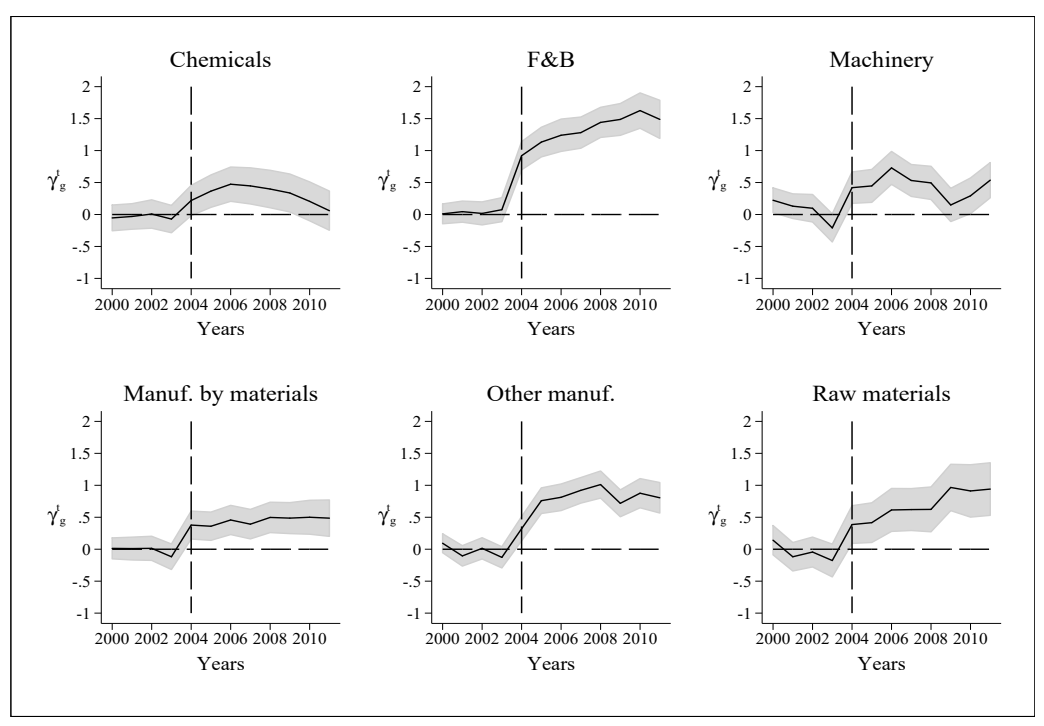


Figure B.5: Group EU10

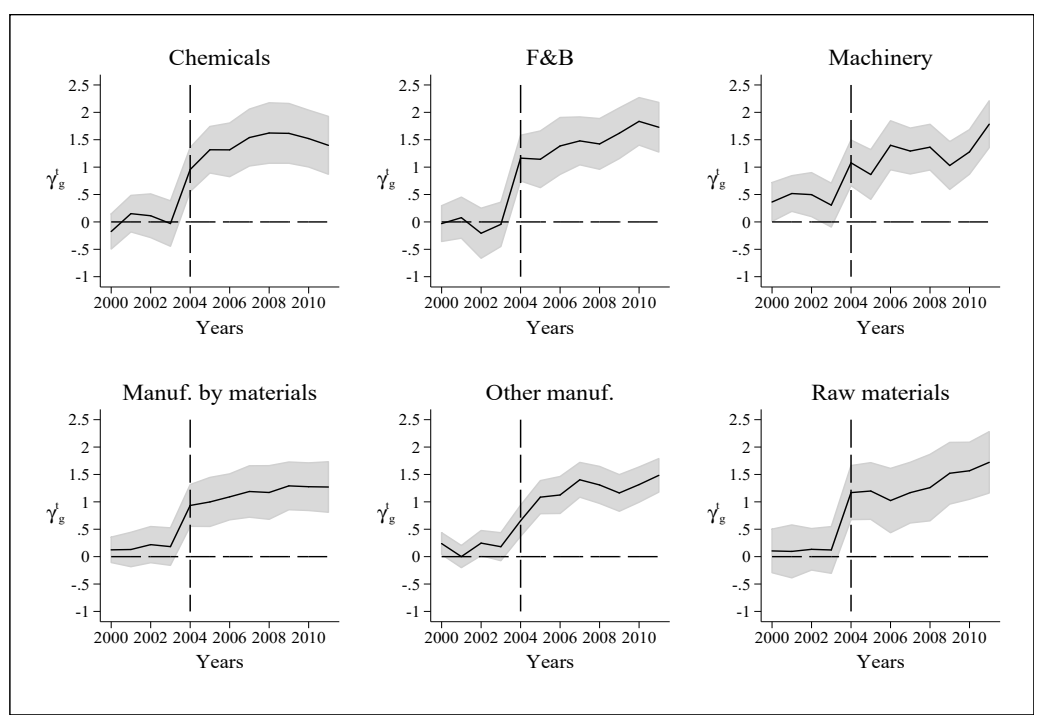

Figure B.6: Group FSU

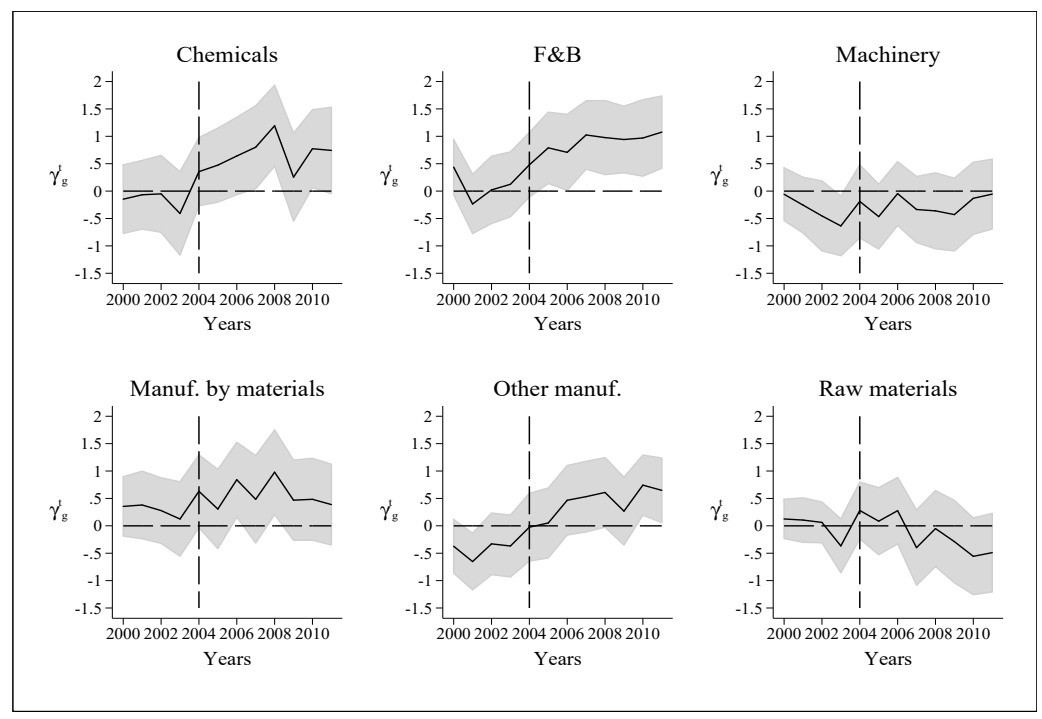

